\title{
SELF-DEFEnCE as a Circumstance Precluding WrongFulness: UndERSTANDing ARTICLE 21 OF THE ARTICLES ON STATE ReSPONSIBILITY
}

\author{
By FEDERICA I PADDEU ${ }^{*}$
}

\begin{abstract}
This study considers self-defence in its function as a circumstance precluding wrongfulness, as codified in Article 21 of the ILC's Articles on State Responsibility. The study examines the development of this provision in the work of the ILC and considers relevant practice by States and international tribunals in relation to the defence. The study explains that self-defence has two functions in international law. The right of selfdefence, codified in Article 51 of the UN Charter and recognised in customary international law, is an exception to the prohibition of force. In the ILC terminology, the right of self-defence is a primary rule. The circumstance precluding wrongfulness of selfdefence, contained in Article 21 ARS, serves to preclude the wrongfulness of potential breaches of obligations (other than the prohibition of force) binding the States involved in an armed conflict, so long as the breach of those obligations is a collateral effect of self-defensive forcible measures adopted in conformity with the requirements of the right of self-defence under international law. In the ILC terminology, this is self-defence in its function as a secondary rule.
\end{abstract}

Keywords: State responsibility, circumstances precluding wrongfulness, self-defence, prohibition of force, countermeasures

\section{INTRODUCTION}

II. Tracing the Development of Article 21 of the Articles on State RESPONSIBILITY

A. Self-defence and the probibition of force: The first reading of the ARS

B. Beyond the probibition of force: Self-defence and other obligations

1. The Nicaragua case

2. Legality of Nuclear Weapons advisory opinion

C. A dual role for self-defence? The second reading of the ARS

III. UNDERSTANDING ARTICLE 21: SELF-DEFENCE AND OTHER OBLIGATIONS

A. Justifying collateral breaches of lanful self-defensive force

1. A justification for forcible measures only

2. The breach of obligations through force

3. 'Collateral breaches' of lawful self-defensive force

B. Self-defence as a circumstance precluding wrongfulness in practice

1. Territorial sovereignty and non-intervention

2. Freedom of commerce and freedom of navigation

3. Legality of maritime exclusion zones

IV. CONClusion

\footnotetext{
LLM, PhD (Cantab), Junior Research Fellow at Queens' College and Associate Fellow at the Lauterpacht Centre for International Law, University of Cambridge. I would like to thank James Crawford, Christine Gray, Christian Tams, Marko Milanović and Surabhi Ranganathan for their helpful comments on earlier drafts of this paper.
} 


\section{INTRODUCTION}

The International Law Commission (ILC or Commission) included self-defence as a 'circumstances precluding wrongfulness' in the Articles on the Responsibility of States for Internationally Wrongful Acts (ARS), which were adopted by the Commission and noted by the General Assembly in 2001. Article 21 of the ARS establishes that:

The wrongfulness of an act of a State is precluded if the act constitutes a lawful measure of self-defence taken in conformity with the Charter of the United Nations. ${ }^{2}$

As explained in the Commission's Commentary, Article 21 does not concern the effects of self-defence on the prohibition of the threat or use of force. With respect to that prohibition, self-defence constitutes an exceptional right which, when successfully invoked, does not constitute 'even potentially' a breach of the obligation not to use force in international relations. Article 21 is aimed, instead, at precluding the wrongfulness of the (potential) breach of other obligations by conduct lawfully taken in self-defence. ${ }^{3}$ The Commission thus identified two functions of self-defence in international law: selfdefence as a primary rule, is an exceptional right intrinsic to the prohibition of force, and self-defence as a secondary rule, is a justification for the breach of other legal commitments caused by (lawful) self-defensive force.

The identification of these two functions of self-defence provides a theoretical explanation for a recurring phenomenon in practice. For example, it is widely accepted that self-defensive force does not constitute a violation of the aggressor State's territorial sovereignty or its right to be free from external interference, even when defensive force occurs within its territory. This conclusion can be deduced from the case law of the International Court of Justice (ICJ), which invariably finds that the use of force which falls short of meeting the requirements of self-defence constitutes, in addition to a breach of the prohibition of force, a breach of the principles of territorial sovereignty and nonintervention. The assumption underlying these findings is that if the conditions of selfdefence are met, there is be no breach of these principles either. ${ }^{4}$ But if the right of selfdefence is an exception to the prohibition on force only, then how to explain the absence of breach of these principles? After all, the principles of territorial sovereignty and nonintervention are distinct from the prohibition of force such that exceptions to the

1 The term 'defence' refers to arguments put forward by a respondent to defeat on the merits a claim of wrongful breach of an international obligation. Insofar as the 'circumstances precluding wrongfulness' operate as 'defences', the term 'defence' as used in this article refers to those circumstances. On circumstances precluding wrongfulness as 'defences' see the Commentary to Chapter V of Part I, para 2, of the Articles on Responsibility of States for Internationally Wrongful Acts (hereinafter ARS and Commentary), annexed to UNGA Res 56/83 (28 January 2002). Furthermore, the expression 'circumstance precluding wrongfulness' is equivalent to the notion of 'justification' current in some domestic legal systems. In domestic law, justifications are defences which exclude the characterisation of conduct as unlawful, see J Dressler, Understanding Criminal Law (Matthew Bender, New York 1987) 176-177. The term 'justification' will also be used in this paper as shorthand for 'circumstances precluding wrongfulness'. This use of terminology is without prejudice to the debate concerning the classification of the international law defences into circumstances precluding wrongfulness and circumstances precluding responsibility (or, in the language of domestic law, justifications or excuses). On this question, see V Lowe, 'Precluding Wrongfulness or Responsibility: A Plea for Excuses?' (1999) 10 EJIL 405; T Christakis, 'Les "circonstances excluant l'illicéité": une illusion optique?" in O Corten et al (eds), Droit du Pouvoir, Pouvoir du Droit: Mélanges offerts à Jean Salmon (Bruylant, Bruxelles 2007) 223.

$2 \quad$ ARS art 21.

$3 \quad$ ARS Commentary to art 21, para 1.

$4 \quad$ See section III.B.1 below. 
prohibition of force only are not applicable to these other principles. ${ }^{5}$ Self-defence in its role as an exception to the prohibition of force cannot, therefore, explain this wrongfulness-precluding effect. It must be, therefore, that self-defence also has another function in international law: that of serving as a justification of these collateral breaches. In this sense, self-defence is no different from countermeasures. While countermeasures' principal function is that of serving the implementation of State responsibility, they also have an additional, incidental function, that of justifying the breach of the rights of the target State taken by way of response to that State's unlawful act. ${ }^{6}$ Self-defence's function as a secondary rule would be, then, incidental to its principal role in protecting the sovereignty and independence of States.

The formulation of (and the need for) self-defence as a secondary rule responds to developments in contemporary international law. In the past, the institution of the state of war governed all of the legal relations existing between the belligerent States. ${ }^{7}$ The state of war 'wholly excluded' the law of peace, and replaced it with the law of war in the relations between belligerents. ${ }^{8}$ In addition, the state of war also produced effects in respect of treaty commitments between belligerent States. Until the end of the 19th century it was accepted that the state of war extinguished all treaty relations between belligerents, as evidenced by the fact that peace treaties usually included clauses for the revival of those instruments. ${ }^{9}$ This extreme effect of war on treaties was subsequently softened, and from the early 20th century onwards it was thought that the state of war merely suspended treaties between belligerents. ${ }^{10}$ Whether treaties were terminated or suspended, the point is that the state of war set aside the normal (peaceful) relations between States, be they customary or conventional, and replaced the law of peace wholly with the law of war as the normative order governing the relations between belligerents. In these circumstances, in which the law of peace and treaty relations were displaced, there was no risk that a State's armed measures during war might constitute a violation of its (peacetime) obligations towards its enemy.

The legal institution of war is of little practical relevance in contemporary international law. Scholarly debates remain as to its compatibility with the UN Charter collective security system, ${ }^{11}$ and save for a few instances of declared formal war States engaged in armed conflict do not usually consider themselves to be in a state of war. ${ }^{12}$ Alongside this development, the existence of war as a legal status is no longer a precondition for the application of the law of armed conflict, now triggered by the actual

5 JM Thouvenin, 'Self-defence' in J Crawford et al (eds), The Law of International Responsibility (OUP, Oxford 2010) 461.

6 See, FI Paddeu, 'Countermeasures' in R Wolfrum (ed), Max Planck Encyclopaedia of Public International Law (OUP, Oxford 2011-, online edition [mpepil.com], forthcoming 2016).

7 The state of war consisted of the situation, condition or status during which the extraordinary law of war substituted the law of peace in the regulation of the relations between the parties to the conflict, see Q Wright, 'When does War Exist?' (1932) 26 AJIL 362, 363.

$8 \quad$ SC Neff, $W$ ar and the Law of Nations (CUP, Cambridge 2005) 177.

$9 \quad$ M Mancini, Stato di guerra e conflitto armato nel diritto internazionale (Giappichelli, Milano 2009) 44; M Mancini, 'The Effects of a State of War or Armed Conflict' in M Weller (ed), Oxford Handbook of the Use of Force in International Law (OUP, Oxford 2015) 988-1013.

10 See, eg, North Atlantic Coast Fisheries Case (Great Britain/US) (1910) 11 RIAA 167, 181 ('International law in its modern development recognises that a great number of Treaty obligations are not annulled by war, but at most suspended by it'). The doubts surrounding this question in the early 20th century were described by CB Hurst, 'The Effect of War on Treaties' (1921) 2 BYIL 37.

11 For a summary of the scholarly debate see Neff, War, 335-340.

12 See the exhaustive review of practice in Mancini, Stato di guerra. 
existence of armed hostilities. ${ }^{13}$ The application of the law of armed conflict, furthermore, does not have the effect of displacing the normal, peacetime, legal relations existing between the States in conflict. As stated by the ICJ, the law of armed conflict constitutes a lex specialis in the situation of armed conflict, ${ }^{14}$ a statement which implies that the lex generalis-the normal legal relations existing between States-remains in the background. ${ }^{15}$ Treaties too are no longer considered as 'ipso facto' terminated or suspended by virtue of the existence of armed hostilities. ${ }^{16}$ While States may wish to suspend treaty relations with the other parties to a conflict, this suspension does not occur by operation of law upon the commencement of armed action. In contemporary conditions, States engaged in armed conflict remain "formally at "peace", as stated by the ILC. ${ }^{17}$

The use of force in contemporary international law thus occurs against the background of the complex web of legal relations binding the States involved in the conflict. In this state of affairs, it is not implausible that such uses of force may infringe other obligations existing between these States. The principles of territorial sovereignty and non-intervention have already been mentioned as rules potentially infringed by uses of force. But these are not the only ones; forcible measures may also infringe other obligations binding the States to the conflict. One such example are commercial obligations, as claimed by the applicant in the Nicaragua case and by Iran in Oil Platforms. ${ }^{18}$ The secondary rule function of self-defence, reflected in Article 21 of the ARS, serves to justify these breaches.

Article 21 and the secondary rule function of self-defence that it codifies have been largely misconceived in both practice and scholarship. The ICJ, for example, failed to grasp the role of the plea of self-defence in the parties' arguments in Oil Platforms. Faced with the Iranian claim of breach of the 1955 Treaty of Amity, Commerce and Navigation, ${ }^{19}$ the United States justified its conduct by reference to the exception relating to essential security interests in Article XX(1)(d) of the Treaty. Crucially, the US invoked, as an alternative and separate ground of defence, Article 21 of the ARS as a circumstance precluding the wrongfulness of its alleged breaches of the 1955 Treaty of Amity. ${ }^{20}$ Both the US and Iran agreed that should the attacks on the oil platforms constitute lawful

\footnotetext{
13 C Greenwood, 'The Concept of War in Modern International Law' (1987) 36 ICLQ 283, 295.

14 Legality of the Threat or Use of Nuclear Weapons (Advisory Opinion) [1996] ICJ Rep 226, 240 (para 25).

15 Thus, the Court found that obligations of 'total restraint' in human rights law and environmental law ought to be taken into account in the assessment of the necessity and proportionality of armed force, see Nuclear Weapons, 242 (para 30). Admittedly, the characterisation of international humanitarian law (IHL) as lex specialis has been criticised in the scholarship, see: M Milanović, 'The Lost Origins of Lex Specialis: Rethinking the Relationship between Human Rights and International Humanitarian Law' in JD Ohlin (ed), Theoretical Boundaries of Armed Conflict and Human Rights (CUP, Cambridge forthcoming), < http://papers.ssrn.com/sol3/papers.cfm?abstract_id=2463957>. Aside from the existence of a normative conflict between IHL and other areas of international law, the underlying point made by the Court is fundamental: that even if there exists an armed conflict the 'peaceful' relations between the States parties to it are not automatically set aside.

16 Draft Articles on the Effects of Armed Conflicts on Treaties, annexed to General Assembly Res 66/99 of 9 December 2011, art 3 and Commentary, in ILC, 'Report of the International Law Commission on the work of its sixty-third session' (26 April-3 June and 4 July-12 August 2011) Doc No A/66/10, $173 \mathrm{ff}$. The Report will appear in ILC Ybk 2011/II, Part Two (not yet published).

17 ARS Commentary art 21, para 2. See also J Crawford, Second Report on State Responsibility, UN Doc A/CN.4/498/Add.2, ILC Ybk 1999/II, Part One, 75 (para 299).

$18 \quad$ See section III.B.3 below.

$19 \quad$ Adopted 15 August 1955, entered into force 16 June 1957, 284 UNTS 93.

20 See, eg, the US Rejoinder, Oil Platforms, 141 (para 5.02); oral statement by Iran, Oil Platforms, at CR 2003/5, 41 (para 29), and at CR 2003/7, 51 (para 3).
} 
measures of self-defence, this circumstance would justify the breach of the 1955 Treaty. The Court did not address the American argument based on Article 21 of the ARS, opting instead to incorporate the law of self-defence into the Treaty by way of interpretation of Article XX(1)(d) ${ }^{21}$ a decision which attracted much criticism both inside the bench ${ }^{22}$ and in the scholarly community. ${ }^{23}$ The Court is not alone in its misunderstanding of this rule. While scholars are frequently engaged with the law on the use of force, ${ }^{24}$ they have rarely discussed the secondary rule aspect of self-defence. Indeed, textbooks usually refer only to the right (primary rule) of self-defence in their treatment of Article 21. ${ }^{25}$ Few specialised works discuss Article 21 in its current ILC conceptualisation as a defence for the breach of other obligations by lawful self-defensive force, ${ }^{26}$ and of these few there are some that claim the rule in Article 21 to be useless. ${ }^{27}$

This study examines Article 21 of the ARS and explains its intended role and scope of application. It proceeds in two parts. First, in Section II it traces the development of this provision at the ILC. As will be shown, while the text of Article 21 underwent only minor modifications between the first and second reading, the understanding of the function of self-defence as a circumstance precluding wrongfulness changed significantly between the two readings. From a provision concerning justification for the infringement of the prohibition of force, the Article on self-defence as a circumstance precluding wrongfulness was modified to concern exoneration for the breach of obligations other than the proscription of force by lawful self-defensive action. Second, in Section III, the paper explores the intended scope of Article 21 and analyses some examples of the justifying effect of self-defence in practice. ${ }^{28}$

21 Oil Platforms (Islamic Republic of Iran v United States of America) [2003] ICJ Rep 161, 182 (para 41).

22 See, eg, Oil Platforms, Judge Higgins Sep Op, 237 (para 46); Judge Buergenthal Sep Op, 278-283; Judge Owada Sep Op, 310 (paras 13-14), 314-319.

23 See, eg, WH Taft, 'Self-Defense and the Oil Platforms Decision' (2004) 29 Yale Journal of International Law 295, 557; P Weil and D Richemond-Barak, 'The Oil Platforms Case Before the International Court of Justice: A Non-Case of International Responsibility' in M Ragazzi (ed), International Responsibility Today: Essays in Memory of Oscar Schachter (Martinus Nijhoff, Leiden 2005) 329.

24 There is now a specialised journal, dedicated to the law on the use of force the Journal on the Use of Force and International Law'.

25 See, eg, A Cassese, International Law (2nd edn, OUP, Oxford 2005) 254; P Daillier et al, Droit international public (8th edn, LGDJ, Paris 2009) 875-876; M Shaw, International Law (6th edn, CUP, Cambridge 2009) 793; V de Oliveira Mazzuoli, Curso de direito international público (6th edn, Revista dos Tribunais, São Paulo 2012) 591-592; J Klabbers, International Law (CUP, Cambridge 2013) 130.

26 To the best of my knowledge, only the following do so: $\mathrm{T}$ Christakis and $\mathrm{K}$ Bannelier, 'La légitime défense en tant que "circonstance excluant l'illicéité"” in R Kherad (ed), Légitimes défenses (LGDJ, Paris 2007) 233; T Christakis and K Bannelier, 'La légitime défense a-t-elle sa place dans un code sur la responsabilité internationale?' in A Constantinides and N Zaikos (eds), The Diversity of International Law: Essays in Honour of Professor Kalliopi K Koufa (Martinus Nijhoff, Leiden 2009) 519; Thouvenin, Self-defence, 455. Two other recent publications address art 21 from the perspective of the right of self-defence rather than as a circumstance precluding wrongfulness, see: C Gutiérrez-Espada, El hecho ilícito internacional (Dykinson, Madrid 2005) 125-128; C Farhang, 'Mapping the Approaches to the Question of Exemption from International Responsibility' (2013) 60 Netherlands Internatioanl Law Review 93.

$27 \quad$ Christakis and Bannelier, Légitime défense, 247ff; Christakis and Bannelier, La légitime défense at-elle sa place, 519. (They use the French term 'inutile'.) For a similar conclusion about art 21, see: $\mathrm{R}$ van Steenberghe, La légitime défense en droit international public (Larcier, Bruxelles 2012) 128.

28 To ensure clarity in the exposition of the argument, this study will refer to the 'right' or 'primary rule' of self-defence when referring to this rule's function in relation to the prohibition of force, and to the 'justification', 'circumstance precluding wrongfulness' or 'secondary rule' when referring to the rule's function in relation to other obligations. This language should not be interpreted, however, as suggesting the existence of two separate rules of self-defence. 


\section{Tracing the DeVelopment of ARticle 21 of the ARticles on State RESPONSIBILITY}

Self-defence first appeared in codifications of the law of responsibility during in the framework of the 1930 Hague Codification Conference. José Gustavo Guerrero, rapporteur on State responsibility to the Committee of Experts set up by the League of Nations in preparation for the Conference, included the 'defence of the rights of the State' as a circumstance in which the State could 'disclaim responsibility' for the violation of obligations owed to foreigners. ${ }^{29}$ The proposed defence was criticised for its vagueness, and Guerrero explained that the 'defence of the rights of the State' included situations such as the requisitioning of foreign property by a belligerent State when this was necessary for the defence of its rights during war. ${ }^{30}$ To reflect Guerrero's thinking, the defence was formulated as 'self-defence against an aggressor State' but it was eventually excluded from the Bases of Discussion prepared for the Codification Conference, since the Conference had not been called upon to deal with the law of war. ${ }^{31}$

Between the 1930 Codification Conference and the next time self-defence would be included in a project on State responsibility, at the ILC, the very notion of selfdefence underwent a significant change. In the interwar years, the right of self-defence, until then an institution of the law of peace which permitted States to resort to force (as a measure short of war) for the defence of their rights, ${ }^{32}$ was attached to the then evolving prohibition of force as an exceptional circumstance. ${ }^{33}$ This development was later included in the UN Charter, in the form of a general prohibition of force in Article 2(4) and its exception in Article 51, provisions which are now accepted to reflect customary law. ${ }^{34}$ Moreover, as noted in the Introduction, the significance of war as a legal institution diminished and the continued relevance of war as a legal status is, to say the least, doubtful.

Roberto Ago, the Commission's second Special Rapporteur on State responsibility, first included self-defence as one of the circumstances precluding wrongfulness in the ILC's codification project. Ago's report focused exclusively on selfdefence in its function as exception to the prohibition of force, and the Article adopted on first reading (draft Article 34) reflected this focus. However, a few years after the adoption of draft Article 34 in 1980, the Nicaragua case, the jurisdiction judgment in Oil Platforms and the Nuclear Weapons Advisory Opinion highlighted some important phenomena associated with the use of force and self-defence in international relations, which the ILC's draft had failed to consider. In particular, that force may breach more

$29 \quad$ League of Nations, Committee of Experts for the Progressive Codification of International Law, Report to the Council of the League of Nations, Doc C.196.M.79.1927.V [C.P.D.I.95(2)], Geneva, 20 April 1927, Conclusion 3(b).

30 League of Nations, Committee of Experts for the Progressive Codification of International Law, Minutes of the First Session, held at Geneva, April 1st to 8th, 1925, C.P.D.I/1st Session/P.V., Geneva 7 May 1925, 96.

31 League of Nations, Conference for the Codification of International Law, Bases of Discussion for the Conference Drawn up by the Preparatory Committee, Doc C.75.M.69.1929.V, vol III (Responsibility of States for Damage caused in their Territory to the Person and Property of Foreigners), 127 (Observations).

32 On this point see, generally, R Lesaffer, 'Too Much History: From War as Sanction to the Sanctioning of War' in M Weller (ed), Oxford Handbook of the Use of Force in International Law (OUP, Oxford 2015) 46-47.

33 See, Neff, War, 303-304.

34 See, eg, Military and Paramilitary Activities in and Against Nicaragua Nicaragua v United States of America) [1986] ICJ Rep 14, $97 \mathrm{ff}$. 
than one obligation at a time and that self-defence could act as a justification in relation to these breaches. These developments were incorporated in the draft by the final Special Rapporteur, James Crawford, during the second reading of the draft and are now reflected in the ARS. Article 21 and its Commentary thus clarify that self-defence has two different functions in international law. First, as an exception to the prohibition of force, it is a (primary) right to ward off an armed attack through force. Second, as a circumstance precluding wrongfulness in the law of responsibility, it is a secondary rule which justifies the violation of obligations other than the use of force by self-defensive armed action.

\section{A. Self-defence and the probibition of force: The first reading of the ARS}

Ago included self-defence as a circumstance precluding wrongfulness in his final report to the ILC, in 1980, in the following terms:

The wrongfulness of an act of a State not in conformity with an international obligation to another State is precluded if the State committed the act in order to defend itself or another State against armed attack as provided for in Article 51 of the Charter of the United Nations. ${ }^{35}$

Ago explained in his report that self-defence was not a 'subjective right', or, what is the same, a Hohfeldian claim-right. In his view, self-defence could not be characterised as a 'subjective right' because it was not possible to identify a correlative obligation to this right: an aggressor State was not under a duty to tolerate the defensive forcible action of another State. ${ }^{36}$ This meant that the invocation of self-defence did not entail the formulation of a legal claim requiring a specific performance (to tolerate the defensive force) from the aggressor State. Instead, according to Ago, through the invocation of self-defence, a State was simply attempting to 'justify' its denial of a 'legitimate legal claim' that could be formulated against it. That is, the invocation of self-defence constituted a denial of the 'legitimate legal claim' of the aggressor State that the self-defensive measure against it was contrary to the prohibition on the use of force. ${ }^{37}$ Ago preferred instead to speak of a faculté (or Hohfeldian liberty) to act in self-defence. ${ }^{38}$

To justify the inclusion of self-defence among the circumstances precluding wrongfulness, Ago pointed emphasised what he thought were commonalities between them. Thus, he argued that self-defence was a 'situation of de facto conditions', ${ }^{39}$ and that in this situation the relevant primary rule was suspended. ${ }^{40}$ The reports do not explain what a 'situation of de facto conditions' is; it probably meant simply that action in selfdefence is triggered by the mere existence of factual circumstances (eg, the existence of

35 R Ago, Eighth Report on State Responsibility - Add.5-7, UN Doc A/CN.4/318/Add.5-7, ILC Ybk 1980/II, 70 (para 124).

36 This is the correlative duty of the right of self-defence as identified by some scholars, eg $\check{\mathrm{C}}$ Čepelka, 'Les conséquences juridiques du délit en droit international contemporain' in Acta Universitatis Carolinae, Iuridica, Monographia (Universita Karlova, Prague 1965) vol 3, 44-46. See also L-A Sicilianos, Les réactions décentralisées à l'illicite. Des contre-mesures à la légitime défense (LGDJ, Paris 1990) 46-47.

37 Analogous views were held by some contemporaneous literature, see eg: G Moursi Badr, 'The Exculpatory Effect of Self-Defence in State Responsibility' (1980) 10 Georgia Journal of International and Comparative Law 1, 1; Sicilianos, Réactions décentralisées, 40-47. For an earlier statement of a similar view, see D Bowett, Self-defence in International Law (Manchester University Press, Manchester 1958) 8-9, also cited by Ago in Eighth Report - Add.5-7, 53 (fn 208).

Ago, Eighth Report - Add.5-7, 53 (para 87).

Id. Generally, R Ago, Eighth Report on State Responsibility, UN Doc A/CN.4/318 and Add.1 to 4,
ILC Ybk 1979/II, 30 (para 55); Ago, 1629th meeting, 9 July 1980, ILC Ybk 1980/I, 235-236 (paras 4-5). Specifically in respect of self-defence, see: Ago, 1629th meeting, 238 (para 17). 
an armed attack). Ago drew a parallel with the state of necessity, but the same can be said about, for example, force majeure: it is a set of factual circumstances (external event with certain characteristics) which creates an impossibility to perform an obligation. ${ }^{41}$

Ago was thus trying to smooth the acceptance of the draft article on self-defence as part of the circumstances precluding wrongfulness and, by extension, as a relevant notion of the law of responsibility rather than as a notion of the law on the use of force. For Ago, there was no doubt that self-defence was a notion that belonged to the law of responsibility; in his view it was the 'circumstance par excellence which precluded wrongfulness'. So 'it simply could not go unmentioned in chapter V of the draft' on State responsibility. ${ }^{42}$ To be sure, he was not alone in conceptualising self-defence in this way. For instance, Gamal Moursi Badr, writing in 1980, explained that:

In the new world legal order, self-defense has become merely a defense against responsibility for the violation of the obligation to refrain from use of force; therefore, its role as an exculpatory factor calls for a more precise definition. ${ }^{43}$

But this was not a widely shared view, and as will be seen shortly, it met with the unyielding opposition of some ILC members. At any rate, it was plainly wrong to treat self-defence as triggered by 'de facto' conditions only: the armed attack, while an objective standard, must also be unlawful. If all it took was the existence of an armed attack, then self-defence could be exercised against self-defence, which is plainly inadmissible. ${ }^{44}$

The majority of the Commission was happy to accept Ago's proposals. ${ }^{45}$ But at least two members, Nikolai Ushakov and Stephen Verosta, vigorously objected to it. They argued that self-defence was not a 'situation of de facto conditions' (and, consequently, not a circumstance precluding wrongfulness) and that in practice States actually perceived it as a right. ${ }^{46}$ Moreover, they objected to the implication of including self-defence among the 'circumstances precluding wrongfulness': that where a State used force in self-defence there was conduct which needed justification, conduct which, therefore, was presumptively in breach of the prohibition to use force in international relations. Yet the practice of States, they noted, seemed very clear that self-defensive force was lawful ab initio, it did not constitute a breach of the prohibition of force, and

\footnotetext{
41 See, generally, Paddeu, 'A Genealogy of Force Majeure in International Law' (2011) 82 BYIL 381.

$42 \quad$ R Ago, 1629th meeting, 239 (para 31).

43 Moursi Badr, Exculpatory Effect, 1.

$44 \quad$ The point was clearly articulated by Lord Stowell in The Maria (1799) 1 C Rob 340, 360-1: 'It is a wild conceit, that wherever force is used, it may be lawfully resisted. A lawful force cannot be lawfully resisted. The only case where it can be so is in the state of war and conflict between two countries, where one party has a perfect right to attack by force, and the other an equal right to resist by force. But, in the relative situation of two countries at peace with each other, no such conflicting rights can possibly co-exist.' 45 P Reuter, 1620th meeting, 26 June 1980, 191 (para 24); S Schwebel, 1621st meeting, 27 June 1980, 191 (para 1); F Vallat, 1621st meeting, 27 June 1980, 194 (para 20); S Tsuruoka, 1627th meeting, 7 July 1980, 220 (para 1); L Díaz-González, 1627th meeting, 7 July 1980, 221 (para 9); J Barboza, 1627th meeting, 7 July 1980, 222 (para 14); RQ Quentin-Baxter, 1627th meeting, 7 July 1980, 222 (paras 16-17); C Pinto, 1627th meeting, 7 July 1980, 222 (para 18); S Sucharitkul, 1628th meeting, 8 July 1980, 231 (para 28), all in ILC Ybk 1980/I. Note also that some members suggested to give the draft article on self-defence a 'special place' within the ARS, see, eg, A Tabibi, 1628th meeting, 8 July 1980, 230 (para 21), ibid.

46 See, eg, NA Ushakov, 1620th meeting, 26 June 1980, 190 (paras 16-17); and later at NA Ushakov, 1635th meeting, 17 July 1980, 272 (para 55); S Verosta, 1628th meeting, 8 July 1980, 229 (para 10), all in ILC Ybk 1980/I. Verosta eventually accepted the Special Rapporteur's proposal, but Ushakov maintained his objection which was recorded in the commentary to draft art 34, see ILC, Report of the International Law Commission on the work of its thirty-second session, UN Doc A/35/10, ILC Ybk 1980/II, Part Two, 60-61 (para 27).
} 
was therefore not in need of justification. While not framed in these terms by Ushakov and Verosta, this exchange between Ago and his critics pointed to fundamental differences as to the conceptualisation of self-defence: as a notion of the law of the use of force (the primary rules) or a notion of the law of responsibility (the secondary rules).

As to the formulation of the provision, Ago's proposed article on self-defence used broad language: it spoke of preclusion of wrongfulness of acts 'not in conformity with an international obligation, ${ }^{47}$ the indefinite article 'an' suggesting that self-defence could operate as a justification in respect of any and all international obligations. Yet, Ago's report focused on one international obligation only: the prohibition of force. The report thus limited the effect of self-defence as a circumstance precluding wrongfulness to the potential breach of the obligation not to use force in international relations. In this sense, self-defence was rather different from the other defences included in the ARS (and from the ARS as a whole): ${ }^{48}$ those defences were of general application, valid as against any and all obligations in international law. In its discussion, the Commission also focused on this legal relation only. Very little attention was paid to the effect of selfdefensive measures on other obligations binding the defending State to its aggressor. The matter was only alluded to, if obliquely, in an observation by Willem Riphagen. Riphagen stated that self-defence could not justify the breach of jus cogens obligations. Surely, he said, rules concerning human rights in armed conflict 'remained valid even in the relationship with an aggressor State. ${ }^{49}$ The observation was brief, but it was a conceptually very astute one. It raised the question of the (uncertain) status of treaties during armed conflict, and contained an acknowledgement that defensive force could produce effects on other 'relationships' binding between the defending and aggressor States beyond the obligation not to use force. The remark went mostly unnoticed in the Commission, and indeed it is not clear that his colleagues grasped the issue at all. ${ }^{50}$

Draft Article 34 was adopted with minimal changes, ${ }^{51}$ and in its commentary the Commission limited the scope of self-defence to preclusion of wrongfulness in relation to the prohibition of force; namely it considered the notion of self-defence exclusively in its relation to the obligation not to resort to force in international relations. Arguably to justify the inclusion of this provision in the draft (and thus respond to Verosta and Ushakov's critiques) the Commentary also states that, by including self-defence in the responsibility project, the ILC was simply drawing 'the inevitable inferences regarding preclusion of the wrongfulness of acts of the State involving such recourse under the conditions that constitute a situation of self-defence. ${ }^{52}$ But the Commission failed to note that the 'inevitable inferences' extended beyond the effect of self-defence on the prohibition on the use of force.

$47 \quad$ Ago, Eighth Report - Add.5-7, 70 (para 124). (emphasis added)

48 The rules on responsibility, as Ago's Fifth Report had extensively demonstrated, were applicable to the breach of any international obligation, regardless of source and content. They were, as such, of general application. See R Ago, Fifth Report on State Responsibility, UN Doc A/CN.4/291 and Add.l and 2, ILC Ybk 1976/II, Part One, 6ff, and the current ARS art 12 and its Commentary.

49 W Riphagen, 1620th meeting, 26 June 1980, 189 (para 5), ILC Ybk 1980/I.

50 Note, however, that at the suggestion of Riphagen and Vallat the ILC excluded the application of draft art 34 to the breach of obligations owed to third States: ILC, Report, thirty-second session, 61 (para 28). For the comments of these two members of the Commission see Riphagen, 1620th meeting, 189 (para 7) (emphasis in original); Vallat, 1621st meeting, 194 (para 22).

51 Draft art 34 read as follows: 'The wrongfulness of an act of a State not in conformity with an international obligation of that State is precluded if the act constitutes a lawful measure of self-defence taken in conformity with the Charter of the United Nations', see ILC, Report, thirty-second session, 52.

$52 \quad$ ILC, Report, thirty-second session, 52 (para 1); see also at 60 (para 23). Echoing Ago's final remarks to the Commission: Ago, 1629th meeting, 239 (para 31). 


\section{B. Beyond the probibition of force: Self-defence and other obligations}

After the adoption of draft Article 34, and before the second reading of the draft, three cases before the ICJ raised a number of issues which challenged and supplemented the ILC's understanding of the notion of self-defence within the law of responsibility. First, in the Nicaragua case, the ICJ was faced with the question whether the breach of a commercial treaty obligation could be justified because the impugned action had allegedly been adopted in the exercise of self-defence. Second, in Oil Platforms, the Court was again faced with a claim for the breach of treaty-based commercial obligations by uses of force. In its 1996 decision on jurisdiction, the Court clarified that international obligations may be breached through any means: be they non-forcible (eg, the decision of a domestic court) or forcible. ${ }^{53}$ Third, in Nuclear Weapons the Court was called to consider the exercise of self-defence and its effect on other obligations binding on the relevant parties, in particular human rights, humanitarian law, and environmental law, thus highlighting that the exercise of self-defence and the subsequent existence of an armed conflict no longer set aside the peaceful legal relations between the States concerned. This section reviews the Nicaragua and Nuclear Weapons decisions, since Oil Platforms essentially reaffirmed the Court's findings in Nicaragua on this point.

\section{The Nicaragua case}

The dispute in Military and Paramilitary Activities in and against Nicaragua arose out of the use of force, through both direct and indirect means (in the form of support for the contra paramilitary group), by the US against Nicaragua in apparent breach of conventional and customary international law. Nicaragua claimed that these forcible actions breached the prohibition of the use of force, its right to territorial sovereignty, the principle of non-intervention, international humanitarian law and the 1956 Treaty of Friendship, Commerce and Navigation. ${ }^{54}$ The US in turn claimed that its use of force had been in self-defence exercised collectively on behalf of Costa Rica, Honduras and El Salvador, all of which had endured (direct and indirect) uses of force from Nicaragua. ${ }^{55}$

In its judgment on the merits, the Court discussed at length the right of selfdefence in international law. In addition to authoritatively articulating the customary law on self-defence, ${ }^{56}$ the Court also explained the purpose of an invocation of self-defence in respect of alleged breaches of international law:

The normal purpose of an invocation of self-defence is to justify conduct which would otherwise be wrongful. If advanced as a justification in itself, not coupled with a denial of the conduct alleged, it may

\footnotetext{
53 Oil Platforms (Islamic Republic of Iran v United States of America), Preliminary Objections [1996] ICJ Rep 803, 811-812 (para 21).

$54 \quad$ Treaty of Friendship Commerce and Navigation (US-Nicaragua) (21 January 1956) 9 UST 449. See, generally, Memorial of Nicaragua on the Merits, in ICJ Pleadings, Military and Paramilitary Activities in and Against Nicaragua (Nicaragua v United States of America), vol IV, esp 59-131.

55 Counter-Memorial of the US on Jurisdiction, in ICJ Pleadings, vol IV, esp 164ff. This invocation was made in the jurisdiction and admissibility phase of the dispute. The US refused to participate in the merits phase, as a protest against the adverse decision on jurisdiction, see Letter from the Counselor for Legal Affairs of the Embassy of the United States of America to the Registrar, 18 January 1985, ICJ Pleadings vol V, 408. The Court, in fulfilment of the requirement of art 53 of its Statute, took this defence into account and discussed it in detail in its merits judgment.

56 On the importance of this judgment see C Gray, 'The ICJ and the Use of Force' in C Tams and J Sloan (eds), The Development of International Law by the International Court of Justice (OUP, Oxford 2013) 242.
} 
well imply both an admission of that conduct, and of the wrongfulness of that conduct in the absence of the justification of self-defence. ${ }^{57}$

Self-defence, it continued, 'removed' the wrongfulness of prima facie violations of international law:

In so far as acts of the Respondent may appear to constitute violations of the relevant rules of law, the Court will then have to determine whether there are present any circumstances excluding unlawfulness, or whether any such acts may be justified upon any other ground. ${ }^{58}$

The Court thus accepted the conceptualisation of self-defence as a notion of the law of responsibility endorsed by the ILC on first reading: it explained the effects of selfdefence using the language of preclusion of wrongfulness. But the Court went beyond draft Article 34, in that it considered self-defence as a possible defence for (forcible) violations of international law generally. The Court was actually drawing the inevitable inferences' for the law of responsibility of the lawful exercise of self-defence in international law.

In its application of these principles to the case before it, the Court considered whether self-defence could justify all of the violations alleged by Nicaragua. It began with the prohibition of force. First the Court ascertained whether there had been a violation of the prohibition of force, ${ }^{59}$ and found that the US had both used direct and indirect force (through support for the contras) against Nicaragua. After finding that this was a 'prima facie violation' ${ }^{60}$ of the prohibition, it discussed and denied that the violation was justified by self-defence because the conditions of the plea were not met in fact. ${ }^{61}$ It then moved on to the other rules allegedly breached. Again, the direct and indirect force of the US against Nicaragua constituted a prima facie breach of the principles of nonintervention and territorial sovereignty. ${ }^{62}$ In both cases, the Court went on to reject that the prima facie breach was precluded by self-defence, since the plea had not been met in fact. ${ }^{63}$ Similarly, with respect to the claim of breach of the 1956 Treaty of Friendship, the Court found that the 'mining of the Nicaraguan ports ... is in manifest contradiction with the freedom of navigation and commerce guaranteed' by Article XIX the Treaty, ${ }^{64}$ which was also not justified by self-defence. ${ }^{65}$

The judgment's approach mirrored the structure of the Nicaraguan argument. In its memorial and its oral pleadings before the Court, Nicaragua had discussed, by way of counterargument, whether self-defence could justify the various breaches it alleged. ${ }^{66}$ Moreover, it is noteworthy that, despite the limitation of draft Article 34 to the relation between self-defence and the prohibition of force only, Nicaragua had referred to the ILC's draft articles on circumstances precluding wrongfulness in addressing possible

\footnotetext{
$57 \quad$ Nicaragua, 44-45 (para 74).

$58 \quad$ Ibid, 107-108 (para 226).

59 Ibid, 118 (paras 227-228).

$60 \quad$ Ibid, $118(228)$

61 Ibid, 119-123.

62 Ibid, 126 (para 247), on prohibition of intervention; 128 (para 251), on territorial sovereignty.

63 Ibid, 126 (paras 247-249), on prohibition of intervention; 128 (para 252), on territorial sovereignty. $64 \quad$ Ibid, 139 (para 278).

65 Ibid, 141 (para 282) (noting that the 'justification of self-defence' had already been 'rejected on the legal level').

66 Memorial of Nicaragua, ICJ Pleadings, vol IV, breaches: at 115-129; justification: 129.
} 
justifications to the breaches of the 1956 Treaty of Friendship, including self-defence. ${ }^{67}$ Neither Nicaragua nor the Court at any point questioned whether self-defence could justify the breach of obligations other than those deriving from the prohibition on the use of force.

\section{Legality of Nuclear Weapons advisory opinion}

The advisory proceedings concerning the Legality of Nuclear Weapons more clearly highlighted the existence of interaction between self-defensive force and international obligations other than the prohibition of force. Indeed, the very question whether selfdefence could justify the breach of other obligations was discussed in the submissions of some States. The Court received two successive requests for advisory opinions on the legality of nuclear weapons. First, in 1993 the World Health Organization (WHO) asked the Court whether in view of the health and environmental effects of nuclear weapons, it was lawful for states to use this type of weapon in armed conflict. ${ }^{68}$ The next year, the UN General Assembly ('GA') asked the Court whether it was lawful to use nuclear weapons in 'any circumstances'. ${ }^{69}$ As between the two proceedings, over 40 States submitted written observations to the Court and many of them also appeared to present oral submissions.

States participating in these proceedings addressed the legality of nuclear weapons from multiple angles. They discussed whether nuclear weapons were lawful per se, and whether other rules of international law may limit or prohibit their use. Among these other rules, States discussed the right of self-defence, humanitarian law, human rights law and environmental law. In the context of the right of self-defence, some States argued that nuclear weapons, so long as their use was necessary and proportionate, were lawful when employed in self-defence. ${ }^{70}$ As the United Kingdom explained, it was impossible to argue that this fundamental, inherent right [of self-defence] has been limited or abandoned on the basis of mere inferences drawn from other rules, whether conventional or customary. ${ }^{71}$ While this may be correct, other States pointed out that nuclear weapons' legality under jus ad bellum rules said nothing as to the possible effect of their use on other rules of international law. For instance, New Zealand stated that 'the right of self-defence cannot be exercised in isolation from other applicable rules and principles of international law', such that even if lawfully used in self-defence nuclear weapons may still breach other rules of international law. ${ }^{72}$ Likewise, Solomon Islands queried 'what use [was] there in justifying behavior by reference to one category of rules where that behavior would violate another category of rules?. ${ }^{73}$ Indeed, even if nuclear

67 While it specifically cited draft art 33 on state of necessity, Nicaragua did not cite draft art 34 on self-defence. In its Memorial, Nicaragua referred generally to the circumstances precluding wrongfulness 'traditionally recognized under customary international law and enumerated in Chapter $\mathrm{V}$ of the draft articles of the ILC concerning State responsibility', in particular, self-defence as invoked by the US. Nicaragua rejected that the treaty breaches could be so justified, see Memorial of Nicaragua, ICJ Pleadings, vol IV, 112 (para 427). In its oral statement, Nicaragua followed the same approach: it referred generally to the draft Articles and then denied that self-defence was made out: ICJ Pleadings, vol V, 190-191.

68 Res WHA46.40, 14 May 1993.

69 UNGA, Res 49/75K (15 December 1994).

70 UK: Written Statement, 20 September 1994, Nuclear Weapons (WHO request), 77-81; Written Statement, 16 June 1995, Nuclear Weapons (GA request), 37-39. France: Written Statement, Nuclear Weapons (WHO request), June 1994, 23-24; oral statement, Nuclear Weapons, CR 95/23, 65-67 (paras 36-37). All the statements, written and oral, can be found at <www.icj-cij.org $>$.

$71 \quad$ UK, oral statement, Legality of Nuclear Weapons, CR 95/45, 33.

72 New Zealand, oral statement, Legality of Nuclear Weapons, CR 95/28, 42.

73 Written Comments of the Government of Solomon Islands, 19 June 1995, Legality of the Threat or Use of Nuclear Weapons (GA request), para 4.73-4.74. 
weapons were lawfully used in self-defence, they could still infringe humanitarian law, human rights law and environmental law. Forcible measures, these States were saying, even if lawfully adopted in self-defence may be the subject of distinct legal appraisals under different legal rules.

The Court, which found that it had no jurisdiction in respect of the WHO request because it fell outside the competence of that body, ${ }^{74}$ rendered an opinion on the GA request in which it addressed the law of self-defence. Even if its comments were brief (and in some respects controversial), ${ }^{75}$ implicit in the Court's opinion was the understanding that in contemporary international law self-defensive action occurs amidst the complex web of legal relations binding on States. The Court described the law of armed conflict as the lex specialis applicable in the circumstances, ${ }^{76}$ a statement that implied that other rules of international law remained in the background not having been excluded or displaced in their entirety by virtue of the existence of the conflict. In particular, the other rules of international law to which the parties had referred in their submissions, human rights law and the protection of the environment, contained certain obligations intended to impose a 'total restraint' on States during military conflict. ${ }^{77}$ These were obligations that could not be breached, even in self-defence. And while these obligations were not intended to 'deprive' States of their right of self-defence, they must nevertheless be taken into account by States in assessing the necessity and proportionality of their uses of force. ${ }^{78}$

Leaving aside the difficult question of the relationship between international humanitarian law and human rights law, the upshot of the Court's finding is that there exist obligations of 'total restraint' which States cannot breach even when they act in selfdefence. As held by the Court, a State acting in self-defence is required to take into account obligations of total restraint in its evaluation of the necessity and proportionality of military measures. But what about obligations of, so to speak, 'lesser' restraint, such as commercial obligations? The Court did not explain how these related to self-defence, but the implication is that the State acting in self-defence is not required to take these into account in its assessment of necessity and proportionality such that its use of force, even if lawful, can potentially constitute a breach of these obligations.

It is to this question that the ILC turned during the second reading of the ARS: could the State exercising self-defence justify the breach of these obligations (of lesser restraint) resulting from its use of force; ${ }^{79}$ or would it be held responsible for those violations even though the breach of the aggressor's rights resulted from force used to fend off that State's aggression?

74 Legality of the Use by a State of Nuclear Weapons in Armed Conflict (Advisory Opinion) [1996] ICJ Rep 66, 84 (para 32).

75 Eg D Bodansky, 'Non liquet and the Incompleteness of International Law' in L Boisson De Chazournes and P Sands (eds), Nuclear Weapons and the International Court of Justice (CUP, Cambridge 1999) 153; M Kohen, 'The Notion of "State Survival" in International Law' in L Boisson De Chazournes and P Sands (eds), Nuclear Weapons and the International Court of Justice (CUP, Cambridge 1999) 293.

$76 \quad$ Nuclear Weapons, 240 (para 25).

$77 \quad$ Ibid, 242 (para 30).

78 Id.

79 That self-defence could act as justification for these breaches was argued by Akande in a commentary of the Court's opinions, see D Akande, 'Nuclear Weapons, Unclear Law? Deciphering the Nuclear Weapons Advisory Opinion of the International Court' (1997) 68 BYIL 165, 185-186. 
The final Special Rapporteur to the ILC on State responsibility, James Crawford, took issue with the understanding of the draft article on self-defence which emerged from the first reading of the ARS. To begin with, he argued that self-defence was not a circumstance precluding wrongfulness in relation to the prohibition of force. Under the UN Charter, in accordance with which the ARS must be interpreted, ${ }^{80}$ self-defence was a condition internal to the prohibition of force: it was an exceptional right which formed part of the definition of the rule itself. Indeed, this was corroborated by the fact that in practice, as had been suggested by numerous States in the Sixth Committee, ${ }^{81}$ when a State acts in self-defence there is not 'even potentially' a breach of the obligation not to use force. ${ }^{82}$ The consequence of this reading, although this is not explicitly stated in the report, is that the norm prohibiting the use of force in international law is defined as follows: 'the use of force is prohibited without self-defence'. This aspect of self-defence, its intrinsic status as part of the prohibition of force, was not what the ARS should be concerned with: the right of self-defence belonged to the primary rules of international law and, as the mantra had by then become, the ARS were limited to the secondary rules of international law only. ${ }^{83}$ In this sense at least, self-defence was not a notion that belonged to the law of State responsibility.

As an aside, it may be noted that Crawford's characterisation of self-defence as an implicit condition of the prohibition of force was necessary to get around the limitation in Article 26 ARS, formulated during the second reading of the draft, which provides that the defences are not applicable to the violation of peremptory rules of international law. ${ }^{84}$ Given the peremptory character of the prohibition of force, ${ }^{85}$ if selfdefence were a circumstance precluding wrongfulness, external to the prohibition of force, then it would not be able to justify why self-defensive force is not unlawful under the prohibition; a conclusion which flies in the face of positive law and experience. ${ }^{86}$

$80 \quad$ See ARS Commentary to art 59, para 2.

81 See, eg, Byelorussia (as it then was), Sixth Committee, Summary record of the 57th Meeting, GAOR, thirty-fifth session, UN Doc A/C.6/35/SR.57, 11 (para 42); Ethiopia: Sixth Committee, Summary record of the 51st Meeting, GAOR, thirty-fifth session, UN Doc A/C.6/35/SR.51, 12 (para 46); France: Sixth Committee, Summary record of the 50th Meeting, GAOR, thirty-fifth session, UN Doc A/C.6/35/SR.50, 13 (para 43); Hungary: Sixth Committee, Summary record of the 55th Meeting, GAOR, thirty-fifth session, UN Doc A/C.6/35/SR.55, 12 (para 45); Mongolia: Sixth Committee, Summary record of the 53rd Meeting, GAOR, thirty-fifth session, UN Doc A/C.6/35/SR.53, 8 (paras 29-30); Spain: Sixth Committee, Summary record of the 55th Meeting, GAOR, thirty-fifth session, UN Doc A/C.6/35/SR.55, 4 (para 11); Trinidad and Tobago: Sixth Committee, Summary record of the 56th Meeting, GAOR, thirtyfifth session, UN Doc A/C.6/35/SR.56, 6 (para 26); and USSR (as it then was): Sixth Committee, Summary record of the 52nd Meeting, GAOR, thirty-fifth session, UN Doc A/C.6/35/SR.52, 14 (para 63). $82 \quad$ Crawford, Second Report, 74 (para 298).

83 Note, however, that the distinction between primary and secondary rules was only ever intended to be a pragmatic one, to be used as an heuristic device to delimit the scope of the Commission's work. Indeed, there is no doubt that the ARS include some rules which may be understood as primary, eg, the obligation not to render aid and assistance in the commission of a wrongful act (ARS art 16, see its Commentary at para 9). Moreover, the very circumstances precluding wrongfulness are, in some measure, primary rules insofar as they direct the conduct of States: States, thus, have a right to take countermeasures. The primary rule character of the defences is clearly explained in David, Primary, 27.

$84 \quad$ ARS art 26 states that: 'Nothing in this chapter precludes the wrongfulness of any act of a State which is not in conformity with an obligation arising under a peremptory norm of general international law.'

85 For a thorough review of practice in this regard: O Corten, Le droit contre la guerre (2nd edn, Paris, Pedone 2014) 341-359.

86 A similar conclusion was reached in respect of the circumstance of consent, see ARS Commentary to art 26, para 6. 
While the role that self-defence plays in relation to the prohibition of force was excluded from the draft, Crawford thought that a provision on self-defence in the ARS nevertheless remained necessary to deal with the type of situation that Nicaragua, Oil Platforms and Nuclear Weapons had exposed: that self-defensive force could violate other obligations binding the parties to an armed conflict. ${ }^{87}$ These cases had to be understood in historical perspective: they were the consequence of the contemporary irrelevance of the legal institution of war (formal war). In modern conditions, States acting in selfdefence were 'formally at peace' with their aggressor. Self-defensive action took place in a context in which all of the 'normal' legal relations which bound the defending State to the aggressor State remained in force. ${ }^{88}$ In practice this meant that in the course of selfdefence a State may violate other obligations towards the aggressor. For example, it 'may trespass on its territory, interfere in its internal affairs, disrupt its trade contrary to the provisions of a commercial treaty, etc. ${ }^{89}$ And this was the real question: did self-defence constitute a justification or an excuse ... in relation to breaches of [these] other obligations ? $^{90}$ Crawford thought it did. So he proposed to modify the draft Article on self-defence to address these types of situations: the self-defending State was thus exonerated for the breach of other obligations so long as the breach was 'related' to its defensive action and that defensive action was in accordance with the UN Charter. ${ }^{91}$

Crawford also added that self-defence could not justify the breach of every obligation. On the authority of the ICJ's Opinion in Nuclear Weapons, the Special Rapporteur proposed to exclude from the scope of the justification obligations of socalled 'total restraint'. ${ }^{92}$ Namely, obligations like those of international humanitarian law and certain international human rights which are 'expressed or intended to apply as a definitive constraint even to States in armed conflict'. ${ }^{93}$ The Commission rejected a proposal to state this in the text of the article, ${ }^{94}$ but agreed to refer to the Commentary the explanation that the validity of self-defence as a circumstance precluding wrongfulness depended on compliance with the rules of the jus ad bellum and the obligations of 'total restraint'.

Crawford thus distinguished between two functions of self-defence in international law. First, self-defence acted as an exceptional right in relation to the prohibition of force-this is self-defence's role as a primary rule of international law.

\footnotetext{
$87 \quad$ Crawford, Second Report, 75 (fn 592).

$88 \quad$ Crawford, Second Report, 75 (para 299).

89 Crawford, Second Report, 74-75 (para 299).

$90 \quad$ J Crawford, 2589th meeting, 17 June 1999, ILC Ybk 1999/I, 159-160 (paras 53-54).

91 The idea was not new. It had already been articulated, albeit with different requirements, by Sir Gerald Fitzmaurice in his Fourth Report on the Law of Treaties: he had envisaged a justification for the non-performance of treaty obligations on the ground of 'legitimate self-defence'. Fitzmaurice's draft article, which was not discussed by the Commission and was eventually left out (together with all other articles concerning performance) from the draft convention on the law of treaties, was limited to the nonperformance of obligations owed by the State acting in self-defence towards third States. See G Fitzmaurice, Fourth Report on the Law of Treaties, UN Doc A/CN.4/120, ILC Ybk 1959/II, 64-5.

92 This language is borrowed from the ICJ's opinion in Nuclear Weapons, 242 (para 30).

$93 \quad$ Crawford, Second Report, 75 (para 301).

94 Z Galicki, 2589th meeting, 17 June 1999, ILC Ybk 1999/I, 161 (para 65). For the proposal, see: Crawford, Second Report, 76 (para 304); see also his remarks to the plenary of the Commission: J Crawford, 2587th meeting, 15 June 1999, ILC Ybk 1999/vol I, 141 (para 32); he later accepted to delete the proposed paragraph, so long as the Commission authorised him to explain that the word 'lawful' covered both the jus ad bellum and the obligations of total restraint: Crawford, 2589th meeting, 160 (para $54)$.

95 Art 21 Commentary, para 6.
} 
Second, self-defence precluded the wrongfulness of acts not in conformity with obligations breached by the self-defending State-this is self-defence's role as a secondary rule of international law. These two functions are, of course, not independent: self-defence's role as a secondary rule is merely incidental to its role as a primary rule. Therefore, to exonerate the breach of other obligations, self-defence must have been lawfully exercised to begin with.

The Commission was generally in agreement with the approach chosen by the Special Rapporteur on the matter of self-defence, as explained in the current Commentary, and adopted what became Article 21 in the following terms:

The wrongfulness of an act of a State is precluded if the act constitutes a lawful measure of self-defence taken in conformity with the Charter of the United Nations.

\section{UndERSTANDing ARTICLE 21: SELF-DEFENCE AND OTHER OBLIGATIONS}

In what circumstances, then, does self-defence operate in its incidental function as a justification for the breach of other obligations? This section will first analyse the intended scope of Article 21, with a view to clarifying the types of situations in which self-defence displays its exonerating power. In particular, it will show that Article 21 is only relevant where there is a use of force, lawfully adopted pursuant to the jus ad bellum, which infringes obligations owed by the self-defending State towards its aggressor. By implication, non-forcible measures adopted by the self-defending State against its aggressor are excluded from the purview of Article 21. Second, this section will provide a review of practice to show that, while the articulation of the secondary rule function of self-defence may be new, it is not ungrounded in practice. Indeed, Article 21 is really the rationalisation of a phenomenon already recurrent in the practice of States.

\section{A. Justifying collateral breaches of lawful self-defensive force}

\section{A justification for forcible measures only}

According to the Commentary to Article 21, self-defence:

may justify non-performance of certain obligations other than that under Article 2, paragraph 4, of the Charter of the United Nations, provided that such non-performance is related to the breach of that provision. ${ }^{96}$

The choice of words is here certainly infelicitous. If a State acting in (lawful) self-defence does not 'not even potentially' breach the prohibition of force, ${ }^{97}$ how can there be 'nonperformance related to the breach' of the prohibition? After all, there is no breach of the prohibition to begin with. Wording aside, the gist of this paragraph is that the nonperformance in question must have been the consequence of a use of force. The prohibition of force can only be breached through the use of force (direct or indirect as it may be), so that a non-performance 'related to' that breach must also have been caused by a use of force.

Consequently, excluded from the scope of Article 21 are non-forcible measures that a State acting in self-defence may adopt against the aggressor State. A State's selfdefence against an armed attack may be accompanied by other measures, non-forcible in character, intended to aid its defensive campaign. For example, the defending State may

$96 \quad$ ARS Commentary to art 21, para 2.

$97 \quad$ Ibid, para 1. 
impose restrictions on the diplomatic and consular relations with the State author of the armed attack; it can adopt restrictive economic measures, such as embargoes or import bans; suspend treaty obligations, or even build security barriers as a means of defence. The legality or wrongfulness of these various measures is different: some are (intrinsically) lawful, some are wrongful and some others, still, can be justified. The question is: what can justify them?

Measures such as the restriction or breaking of diplomatic relations with an aggressor State are lawful. Indeed, as the Court clarified in Tehran Hostages States are under no obligation to maintain diplomatic relations, so that the unilateral restriction on those relations does not infringe any rights of the aggressor State. ${ }^{98}$ These kinds of measures are perhaps better viewed as a type of retorsion, which are unfriendly though lawful acts which may be adopted in response to either unfriendly or wrongful acts. ${ }^{99}$

But other measures may infringe the rights of the aggressor State. This was the case, for instance, of the import bans imposed on Argentine products by the UK and other States (both European Community (EC) and non-EC) ${ }^{100}$ following the Argentine attack on the Falklands/Malvinas in $1982 .{ }^{101}$ The legality of these measures under the General Agreement on Tariffs and Trade (GATT) was contested by Latin American States, ${ }^{102}$ and eventually the States imposing the ban implicitly conceded that the measures affected Argentina's rights under the GATT, ${ }^{103}$ and under agreements on trade in textiles and trade in mutton and lamb. ${ }^{104}$ The suspension of bilateral civil aviation agreements with Argentina by both West Germany and New Zealand as a result of the conflict in the Falklands/Malvinas also affected Argentina's rights. ${ }^{105}$ Equally, the construction of a barrier by Israel in its own territory and in occupied Palestinian territory, a non-forcible measure of self-defence as the Israeli permanent representative to the UN explained, ${ }^{106}$ affected the rights of the local Palestinian population.

Christakis and Bannelier have argued that these measures can be justified pursuant to Article 21. ${ }^{107}$ But the argument is not convincing, for both logical and positive law reasons. Article 21 reflects an incidental function of the exercise of selfdefence: for Article 21 to operate, the relevant measure must fall within the purview of

98 United States Diplomatic and Consular Staff in Tehran [1980] ICJ Rep 3, 40 (para 86): noting that States have the power to 'break off diplomatic relations'. As such, restrictions on those relations cannot be a breach of international law. See K Trapp, State Responsibility for International Terrorism (OUP, Oxford 2011) 184 (fn 5).

99 Commentary to Chapter II of Part III of the ARS, para 3. On retorsion see generally T Giegerich, 'Retorsion' in R Wolfrum (ed), Max Planck Encyclopaedia of Public International Law (OUP, Oxford 2011-, online edition [mpepil.com]).

$100 \quad$ Keesing's (1982) 31532.

101 Id.

102 OAS, Resolution I on the Serious Situation in the South Atlantic, Second Plenary session of the Twentieth meeting of Consultation of Ministers of Foreign Affairs, 28 April 1982, (1982) 21 ILM 669, at 670-1.

103 Joint Communiqué (EC, Canada, Australia), on Trade Restrictions Affecting Argentina Applied for Non Economic Reasons, GAT'T Doc. L/5319/Rev.1 at para 1 b.

104 Sicilianos, Réactions décentralisées, 163-164; C Tams, Enforcing Obligations Erga Omnes in International Law (CUP, Cambridge 2005) 215.

$105 \quad$ Keesing's (1982) 31533.

106 Statement of Israeli Permanent Representative to the United Nations, General Assembly, Summary Record of the 21 st Meeting, GAOR tenth emergency special session, 20 October 2003, UN Doc A/ES-10/PV.21, 6.

$107 \quad$ Christakis and Bannelier, Légitime défense, 253; Christakis and Bannelier, La légitime défense a-telle sa place, 528. Indeed, they argue that this is the only possible role of art 21. 
the right of self-defence, codified in Article 51 of the UN Charter. The right of selfdefence is an exception to the prohibition of force, so that if the prohibition is limited to military force (direct or indirect as it may be) then the exception must be about the use of military force as well: the whole point of an exception is to exclude the application of the (general) rule from conduct which would otherwise fall within the domain of that (general) rule. ${ }^{108}$ Consequently, if the right of self-defence (the primary rule) is limited to permitting uses of force, ${ }^{109}$ then Article 21 must of necessity concern uses of force. As a result, non-forcible unlawful measures against aggressors are excluded from its scope.

This conclusion is corroborated by the practice of States and the case-law of international tribunals. In the examples given above, for instance, States did not actually rely on self-defence to justify the infringement of the aggressor's rights by their nonforcible measures. Australia, Canada and the EC States adopted import bans against Argentina in 1982, following the invasion of the Falklands/Malvinas; these measures, as the States adopting them recognised, constituted infringements of the rights of Argentina under the GATT and under other WTO-covered treaties. In a joint communiqué, these Stats justified the infringement of Argentina's rights under the GATT by reference to the exception in GATT Article XXI. ${ }^{110}$ The language of the communiqué was, to be sure, vague as these States spoke of justification based on 'their inherent right of which article XXI of the General Agreement is a reflection'. This language thus suggested that the ground of justification was not based on Article XXI itself, but rather on an unidentified norm of customary law. ${ }^{111}$ In addition, the breach of the other WTO-covered treaties could not be justified under Article XXI, so the justification for that infringement required a renvoi to customary law as well. ${ }^{112}$ In analysing these examples, some scholars have argued that the customary ground of justification at issue was (collective) selfdefence. ${ }^{113}$ Nevertheless, these States did not, at any point, invoke self-defence in relation to the import bans, even though the UK had invoked this right in support of its military reaction against the Argentine invasion. ${ }^{114}$ Only a statement by the Canadian Secretary of State for External Affairs in the Commons came close to an invocation of collective selfdefence. ${ }^{115}$ It seems, rather, that the customary justification relied on by these States was countermeasures: Belgium (speaking on behalf of the EC) appeared to rely on this notion. ${ }^{116}$

108 D Unterhalter, 'Allocating the Burden of Proof in WTO Dispute Settlement Proceedings' (2009) 42 Cornell International Law Journal 209, 212-213. See generally, GL Williams, 'The Logic of "Exceptions"” (1988) 47 CLJ 261.

109 See, eg, Sicilianos, Réactions décentralisées, 293-294; I Scobbie, 'Smoke, Mirrors and Killer Whales: The International Court's Opinion on the Israeli Barrier Wall' (2004) 5 German Law Journal 1107, 1128-1129; T Gazzini, The Changing Rules on the Use of Force in International Law (Manchester University Press, Manchester 2005) 129; Y Dinstein, War, Aggression and Self-defence (5th edn, CUP, Cambridge 2012) 242 (describing self-defence as 'lawful counter-force').

110 Joint Communiqué (EC, Canada, Australia), on Trade Restrictions Affecting Argentina Applied for Non Economic Reasons, GATT Doc. L/5319/Rev.1 at para 1b.

$111 \quad$ See Tams, Enforcing, 216; M Dawidowicz, Public Law Enforcement, 371.

112 Id.

113 Eg JL Dewost, 'La Communauté, les Dix et les "sanctions" contre l'Argentine - De la crise iranienne à la crise des Malouines' (1982) 28 Annuaire Français de droit international 215, 231; Dawidowicz, 'Public Law Enforcement without Public Law Safeguards? An Analysis of State Practice on Third-Party Countermeasures and Their Relationship to the UN Security Council' (2006) 77 BYIL 333, 373-374.

114 Tams, Enforcing, 216; EK Proukaki, The Problem of Enforcement in International Law (Routledge, London 2011) 160.

115 A de Mestral, 'Canadian Practice in International Law during 1982' (1983) 21 Canadian Yearbook of International Law 327, 337

$116 \quad$ UN Doc S/PV.2363, 23 May 1982, 12 (paras 131-132). 
Also in the context of the Falklands/Malvinas war, both West Germany and New Zealand had suspended bilateral aviation agreements with Argentina; suspensions which were understood to infringe the rights of Argentina. ${ }^{117}$ Again, self-defence was not relied upon as justification. West Germany, for instance, invoked the right of suspension inherent in the bilateral aviation agreement with Argentina. ${ }^{118}$

As to international case-law, in Nicaragua the Court excluded the possibility that the economic embargo imposed by the US against Nicaragua might be justified as a measure of self-defence. ${ }^{119}$ While in relation to the various violations caused by the US forcible measures self-defence (including violations of the 1956 Treaty of Amity) was an available though unsuccessful justification, ${ }^{120}$ the Court discussed the legality of the embargo exclusively under the 1956 Treaty of Friendship and its essential security exception. ${ }^{121}$ In Palestinian Wall, Israel had argued before the GA that the construction of the wall was 'consistent with Article 51' of the UN Charter. ${ }^{122}$ In particular, Israel argued that if the right of self-defence allowed the use of force against an aggressor (in the case, terrorist attacks), then surely it also allowed the use of non-forcible measures to that end. ${ }^{123}$ The Court did not address this point in its Opinion, having rejected that Israel was entitled to exercise self-defence to begin with. However, Judge Higgins clarified in her separate opinion that the right of self-defence does not extend to non-forcible measures such as the construction of the wall. ${ }^{124}$

As this brief review shows, States often adopt non-forcible measures against their aggressors, measures which can be either (intrinsically) lawful or constitute infringements of the rights of the aggressor. The notion of self-defence may not provide a basis to justify such the measures' infringement of rights of the aggressor State. But this does not mean that the measures will always be unlawful. As evidenced by the practice mentioned, States have at their disposal at least two mechanisms to address the (il)legality of their measures. Firstly, according to the ILC's Articles on the Effects of Armed Conflict on Treaties, a State acting in self-defence can suspend in whole or in part the operation of a treaty to which it is a Party insofar as that operation is incompatible with the exercise of the right of self-defence, ${ }^{125}$ an entitlement which is broader than that allowed to the aggressor State. ${ }^{126}$ Whether armed conflict does, in itself, constitute a customary ground for the suspension of treaties remains in dispute and the ILC's Articles on the matter are not considered to reflect customary law. ${ }^{127}$ However, the actual existence of an armed

\footnotetext{
$117 \quad$ Keesing's (1982) 31533.

118 H Lindemann, 'Die Völkerrechtliche Praxis der Bundesrepublik Deutschland im Jahr 1982' (1984)

44 Zeitschrift für ausländisches öffentliches Recht und Völkerrecht 495, 557-8.

$119 \quad$ Nicaragua, 138 (para 276).

$120 \quad$ As noted above, in Section II.B.1.

121 Nicaragua, 141 (para 282). Note that it is in that same paragraph, that the Court rejected the plea of self-defence in relation to the breach of the 1956 Treaty by forcible measures (eg, the mining and attack of Nicaraguan waters and ports).

122 Statement of Israeli Permanent Representative to the United Nations, A/ES-10/PV.21, 6.

123 Ibid.

124 Legal Consequences of the Construction of a Wall in the Occupied Palestinian Territory [2004] ICJ Rep 136, Judge Higgins Sep Op, 215-216 (para 35).

125 Draft Articles on the Effects of Armed Conflicts on Treaties (n 15), art 14 and Commentary.

126 Art 15 of the Draft Articles and Commentary (n 15), stating that an aggressor State 'shall not terminate or withdraw from a treaty or suspend its operation as a consequence of an armed conflict that results from the act of aggression if the effect would be to the benefit of that State.'

$127 \quad$ Y Ronen, 'Treaties and Armed Conflict', (2013) Hebrew University of Jerusalem Research Paper No 01-13 (January 2013), section 2, <http://ssrn.com/abstract=2197704>. The paper will appear in: C Tams et al (eds), Research Handbook on the Law of Treaties (Elgar, London, forthcoming). Cf Mancini, Stato di guerra, 305-306. Contrast, in this connection, the ICJ's acceptance that the 1955 Iran-US Treaty of Amity
} 
conflict could constitute a relevant factual situation giving rise to other customary grounds of suspension, such as fundamental change of circumstances or impossibility of performance. ${ }^{128}$ That an armed conflict may give rise to a fundamental change of circumstances was accepted by Court of Justice of the European Communities in the 1998 Racke case. ${ }^{129}$ Equally, Ethiopia relied on the 'fundamental transformation of circumstances' caused by the armed conflict to support its contention that an agreement regarding pensions with Eritrea had terminated. ${ }^{130}$ Secondly, States may rely on the notion of countermeasures as justification for these acts, ${ }^{131}$ as evidenced by the practice in relation to Argentina during the Falklands/Malvinas conflict. ${ }^{132}$

Article 21 was not intended to expand the content of the right of self-defence pursuant to Article 51 of the UN Charter. It merely provides for an incidental function of self-defence in international relations, so that it can display its justificatory effects only where the actual force is adopted in accordance with the relevant rules of the jus ad bellum. Measures not covered by the jus ad bellum or unlawful under that body of law may not, therefore, be justified under Article 21.

\section{The breach of obligations through force}

Article 21, then, concerns exclusively forcible measures. The provision is not, however, a simple confirmation of the legality of action adopted under the relevant customary and conventional law (Article 51 of the Charter). Self-defensive action, which complies with the requirements of the relevant primary rules, is lawful and does not need further justification. ${ }^{133}$ If this were the purpose of Article 21, then it would be at best a redundant provision.

It is not uncommon in international law that a given conduct may be the subject of appraisal under different, sometimes conflicting, legal norms. This phenomenon was evidenced by the Southern Bluefin Tuna dispute between Australia and New Zealand, on one side, and Japan, on the other. One of the questions posed to the Tribunal established under the Annex VII of the UN Convention on the Law of the Sea (UNCLOS) in that case was whether the dispute between those States, which concerned Japanese

remained in force in Oil Platforms with the decision of the Eritrea-Ethiopia Claims Commission in Final Award-Pensions (Eritrea's Claims 15, 19 \&23), 19 December 2005, <www.pca-cpa.org>. The Commission held that pensions agreements between these two States had been, at least, suspended, see paras 25-32. It explained this view by stating that 'parties should be presumed to intend that such treaties be at least suspended during the hostilities' (at para 30), meaning that the armed conflict could on its own constitute a ground of suspension.

128 The parties could not rely on the analogous grounds in the VCLT, since pursuant to Art 73 the VCLT is not applicable to situations of armed conflict. On this question, see K Bannelier, 'Les effets des conflits armés sur les traités: et si la Convention de Vienne et le droit de la responsabilité suffisaient?’ in O Corten et al (eds), Droit du Pouvoir, Pouvoir du Droit: Mélanges offerts à Jean Salmon (Bruylant, Bruxelles 2007) 125; B Tan Zhi Peng, 'The International Law Commission's Draft Articles on the Effects of Armed Conflicts on Treaties: Evaluating the Applicability of Impossibility of Performance and Fundamental Change' (2013) 3 Asian JIL 51. Ronen apparently accepts the application of the relevant conventional rules in the VCLT to armed conflict: Treaties and Armed Conflict, section 2.3.

129 A Racke GmbH \& Co v Hautprollamt Mainz (16 June 1998) CJEC Case C-162/96.

130 Eritrea-Ethiopia Claims Commission, Final Award-Pensions (Eritrea's Claims 15, 19 \& 23), para 24.

131 Scobbie, Killer Whales, 1129; Christakis and Bannelier, Légitime défense, 253; and Christakis and Bannelier, La légitime défense a-t-elle sa place, 528.

132 Indeed, scholars have analysed these instances as part of the law of countermeasures, eg: David, Sanctions économiques, 160ff; Sicilianos, Réactions décentralisées, 262; Tams, Enforcing, 216; Dawidowicz, 'Public Law Enforcement', 373-4; Proukaki, Problem of Enforcement, 156-163.

133 Christakis and Bannelier, Légitime défense, 253; also in Christakis and Bannelier, La légitime défense a-t-elle sa place, 528. 
overfishing of Southern Bluefin tuna, arose under UNCLOS or under the Convention for the Conservation of Southern Bluefin Tuna (CCSBT) between those three States. ${ }^{134}$ Japan argued that its conduct was regulated only by the CCSBT, whereas the applicant States argued that the conduct was regulated by both the CCSBT and UNCLOS. The Tribunal sided with the applicants, holding that it was common in 'international law and State practice for more than one treaty to bear upon a particular dispute' and that, accordingly, there was no reason why a given act of a State may not constitute a breach of obligations under more than one treaty, especially since there was 'frequently a parallelism of treaties' in international law. ${ }^{135}$ What is more, these parallel obligations may lead to distinct legal appraisals: State conduct could be lawful pursuant to one rule of international law but unlawful under another, as the Annex VII arbitral tribunal acknowledged in the MOX Plant dispute ${ }^{136}$ and by the ICJ in Croatia v Serbia. The Court's statement in Croatia v Serbia is especially clear in this regard: 'There can be no doubt that, as a general rule, a particular act may be perfectly lawful under one body of legal rules and unlawful under another. ${ }^{, 137}$

The existence of parallel and sometimes conflicting obligations has been at the core of the fragmentation debate. ${ }^{138}$ Even though conflicting obligations may be the byproduct of strategically devised policies of States ${ }^{139}$ they are more often than not simply the consequence of international law's development through a process of 'accretion and cumulation' rather than erosion and reduction, as explained by the Southern Bluefin Tuna Tribunal. ${ }^{140}$ The upshot is that an act of a State may be in breach of multiple obligations at the same time, or be in breach of some but not other obligations. This is true whether the act in question is a non-forcible one (like Japan's extra-quota fishing of Southern Bluefin tuna) or a forcible one.

State acts taking the form of a use of force may, as well, affect multiple obligations of the acting State. ${ }^{141}$ Since the existence of an armed conflict does not have

134 Southern Bluefin Tuna Case (Australia v Japan; New Zealand v Japan) (Jurisdiction and Admissibility) (2000) 23 RIAA 1, 38 (para 48). For the conventions, see: United Nations Convention on the Law of the Sea (UNCLOS) (adopted 10 December 1982, entered into force 16 November 1994), (1982) 1833 UNTS 397; Convention for the Conservation of Southern Bluefin Tuna (CCSBT) (adopted 10 May 1993, entered into force 20 May 1994), (1994) 1819 UNTS 360.

135 Southern Bluefin Tuna, 40 (para 52).

136 The dispute between Ireland and the UK over the mixed oxide fuel (MOX) plant at Sellafield, on the Irish Sea, concerned the Convention for the Protection of the Marine Environment of the North-East Atlantic (OSPAR Convention) (adopted 22 September 1992, entered into force 25 March 1998) (1992) 2354 UNTS 67, UNCLOS and EC law, and gave rise to multiple proceedings in international courts and tribunals. Precisely in view of the prospect of incompatible judicial and arbitral decisions on the basis of distinct obligations of the parties under UNCLOS and EC law, the UNCLOS Annex VII Arbitral Tribunal suspended proceedings pending a decision of the ECJ, see: The MOX Plant Case (Ireland $v$ UK) (Order No 3, 24 June 2003) UNCLOS Annex VII Tribunal, 9 (para 28) <www.pca-cpa.org>. See also the President's Statement, 13 June 2003, at para 11, <www.pca-cpa.org>. For an overview of the dispute and the various proceedings see: RR Churchill, 'MOX Plant Arbitration and Cases' in R Wolfrum (ed), Max Planck Encyclopaedia of Public International Law (OUP, 2007-, online edition [www.mpepil.com]).

137 Application of the Convention on the Prevention and Punishment of the Crime of Genocide (Croatia v Serbia), ICJ Judgment (Merits), 3 February 2015, para 474. (not yet reported)

138 On which see: M Koskenniemi and P Leino, 'Fragmentation of International Law? Postmodern Anxieties' (2002) 15 LJIL 553.

139 See, generally, S Ranganathan, Strategically Created Treaty Conflicts and the Politics of International Law (CUP, Cambridge 2014).

$140 \quad$ Southern Bluefin Tuna, 40 (para 52). The metaphor was taken from the arguments made on behalf of applicants by James Crawford, see First Round Presentation of Australia and New Zealand, 8 May 2000, Southern Bluefin Tuna, 121 (of the un-paginated pdf document), <https://icsid.worldbank.org/>.

$141 \quad$ See Kammerhofer, Oil's Well that Ends Well?, 704. 
the effect of setting aside the obligations, customary or conventional, binding on the parties to the conflict it becomes possible for forcible measure to breach, at one and the same time, obligations beyond the prohibition of force. This was implicit in the ICJ's Nicaragua judgment, and was later upheld in no uncertain terms in the Oil Platforms case. In Oil Platforms, Iran's claim concerned the breach of the 1955 Treaty of Amity through the forcible attacks on, and destruction of, Iranian offshore oil facilities. Before the Court, the US had presented an argument to the effect that the Treaty could not be breached through the use of force, ${ }^{142}$ to which the Court replied that:

The Treaty of 1955 imposes on each of the Parties various obligations on a variety of matters. Any action by one of the Parties that is incompatible with those obligations is unlawful, regardless of the means by which it is brought about. A violation of the rights of one party under the Treaty by means of the use of force is as unlawful as would be a violation by administrative decision or by any other means. ${ }^{143}$

In short: in addition to constituting a possible infringement of the prohibition of force, a military measure can also constitute an infringement of a treaty commitment, such as the 1955 Treaty of Amity between the US and Iran.

This conclusion-that force may breach multiple obligations at once-has underpinned subsequent disputes submitted to the ICJ and other arbitral tribunals. In the majority of disputes concerning the use of force brought to the ICJ, applicant States have claimed that by the use of force the respondent has breached the prohibition of force as well as the principles of non-intervention and territorial sovereignty. Occasionally, the breach of other obligations, conventional or customary, was also claimed. These claims are briefly reviewed here in chronological order. ${ }^{144}$

Nicaragua's applications against Costa Rica ${ }^{145}$ and Honduras, ${ }^{146}$ arising out of the same circumstances at the origin of the Nicaragua case, maintained that through the use of force respondents had breached the prohibition of force, and the principles of nonintervention and territorial sovereignty. An identical claim of breach of these obligations was presented by Cameroon in Cameroon v Nigeria in relation to Nigeria's military presence in the Bakassi Peninsula and Lake Chad, areas over which Cameroon claimed title. ${ }^{147}$ In Aerial Incident of 3 July 1988, in addition to the breach of these obligations, ${ }^{148}$

142 In general, see US Memorial on Preliminary Objection, Oil Platforms, 50-53; US statement, CR $96 / 16,31$. The argument was made especially clear in relation to the claim concerning the breach of art IV of the Treaty on fair and equitable treatment, see: US statement CR 96/13, 23-25. The US stated that art IV concerns 'measures' of an internal type such as 'administrative or regulatory activities', it does not regulate 'actions taken internationally by a party in conducting its foreign relations. It certainly has no relevance to actions involving the use of force', at 24-25, the implication being that a use of force could not constitute one of the 'measures' regulated by art IV. For an overview of the US's jurisdictional arguments in this case see C Gray, 'The Use and Abuse of the International Court of Justice: Cases concerning the Use of Force after Nicaragua' (2003) 14 EJIL 867, 873-874.

143 Oil Platforms, Preliminary Objections, 811-812 (para 21).

$144 \quad$ By the date of institution of proceedings.

145 Border and Transborder Armed Actions (Nicaragua v Costa Rica), Memorial of Nicaragua, 19 August 1987, ICJ, 55ff (non-intervention), 109 (territorial sovereignty), chapter V (non-use of force). The case was discontinued at the request of Nicaragua: Border and Transborder Armed Actions (Nicaragua v Costa Rica), Order of 19 August 1987, [1987] ICJ Rep 182.

$146 \quad$ Border and Transborder Armed Actions (Nicaragua v Honduras), Application instituting proceedings, 28 July 1986, ICJ, 5-7. In a judgment of 1988, the ICJ found it had no jurisdiction to entertain Nicaragua's claims: Border and Transborder Armed Actions (Nicaragua v Honduras), Jurisdiction and Admissibility, [1988] ICJ Rep 69.

147 Cameroon statement, Cameroon v Nigeria, CR 2002/7, 36 (para 7). 
Iran claimed that the shooting down of an Iranian civil aircraft flying over Iranian airspace by a US military vessel constituted a breach of the Chicago Convention on Civil Aviation and of the 1955 Treaty of Amity, ${ }^{149}$ the latter of which Iran invoked again in the Oil Platforms case dealt with in more detail below.

Almost all of the proceedings instituted before the ICJ in 1999 concerned the use of force by States. The Aerial Incident of 10 August 1999 concerned the shooting down of a Pakistani military aircraft flying on Indian airspace by India's air forces plane. In its application, Pakistan claimed that this action by India violated the prohibition of force under the UN Charter and customary law, its territorial sovereignty and a 1961 bilateral treaty on Prevention of Air Space Violations. ${ }^{150}$ The Legality of Use of Force cases, between the then Federal Republic of Yugoslavia (FRY) and ten North Atlantic Treaty Organization ('NATO') member States, concerned alleged violations of multiple international legal rules by NATO's airborne military campaign of February and March 1999. The FRY argued that the campaign infringed a number of customary law obligations, including the prohibition of force, the principles of non-intervention and territorial sovereignty, various obligations arising under the law of armed conflict, environmental law, human rights, and the obligation to respect freedom of navigation on international rivers, as well as the respondents' obligations under the Genocide Convention. ${ }^{151}$ While none of the cases reached the merits, it should be noted that in the preliminary stages of the case neither the parties nor the Court disputed that in principle the use of force could breach the obligations at the heart of the claims. Even in respect of genocide, it was held that in the presence of the requisite genocidal intent an aerial bombardment could constitute a breach of the prohibition to engage in this crime. ${ }^{152}$ Also in 1999, the DRC instituted proceedings against Burundi, ${ }^{153}$ Rwanda ${ }^{154}$ and Uganda, ${ }^{155}$ arising out of the armed conflict which had ravaged the region for many years. In all cases, the DRC claimed breaches of the obligation of non-use of force and the principles of non-intervention and territorial sovereignty. The case against Burundi was withdrawn, ${ }^{156}$ and the ICJ found it lacked jurisdiction in the case against Rwanda. ${ }^{157}$ The

148 Memorial of Iran, Aerial Incident of 3 July 1988 (Iran v USA), 186-193. After written pleadings on preliminary objections, the parties settled the dispute and the case was removed from the ICJ's docket list: Aerial Incident of 3 July 1988 (Iran v US A), Order of 22 February 1996 [1996] ICJ Rep 9.

149 Memorial of Iran, Aerial Incident, 146 (Chicago Convention), 182 (Treaty of Amity), 238 (both).

150 Application instituting proceedings (21 September 1999), Aerial Incident of 10 August 1999 (India v Pakistan), section II. The Court went on to find that it lacked jurisdiction: Aerial Incident of 10 August 1999 (India v Pakistan), Jurisdiction of the Court, [2000] ICJ Rep 12.

151 Legality of the Use of Force (Federal Republic of Yugoslavia v Belgium) [2004] ICJ Rep 279, 283 (para 1).

152 This is implied in the Court's statement that 'the threat or use of force against a State cannot in itself constitute an act of genocide' without proof of the required genocidal intent: Legality of the Use of Force (Federal Republic of Yugoslavia v Belgium), Provisional Measures, Order of 2 June 1999 [1999] ICJ Rep 124, 138 (para 40). This view had been argued by several of the respondent States. See, eg, the memorials on preliminary objections of Belgium, 112 (para 342); Canada, 38 (para 132); Germany, 44 (para 3.44); and Italy, 14, all at $<$ www.icj-cij.org $>$.

153 Application instituting proceedings (23 June 1999), Armed Activities on the Territory of the Congo (DRC v Burundi), 15-19.

154 Application instituting proceedings (23 June 1999), Armed Activities on the Territory of the Congo (DRC v Rwanda), 16-19. The DRC withdrew this application, and subsequently submitted another in 2002, in which it claimed that through force Rwanda had breached a number of treaties, see: DRC $v$ Rwanda (New Application: 2002).

155 Memorial of the DRC, DRC v Uganda, 160-193.

156 Armed Activities on the Territory of the Congo (DRC v Burundi) [2001] ICJ Rep 3.

157 Armed Activities on the Territory of the Congo (New Application: 2002) (Democratic Republic of the Congo $v$ Rwanda), Jurisdiction and Admissibility, [2006] ICJ Rep 6. 
case against Uganda, which proceeded to the merits, will be addressed in more detail below.

The breach of multiple obligations through forcible means is also at issue in two cases currently pending before the ICJ: in Certain Activities between Costa Rica and Nicaragua (now joined with the Nicaraguan claim against Costa Rica for alleged violations of sovereign rights) ${ }^{158}$ and in Nicaragua $v$ Colombia. Both cases concern the conduct adopted by the respective respondents, Nicaragua and Colombia, following ICJ boundary decisions adverse to them. The pleadings in neither case are publicly available as the proceedings are on-going. Costa Rica's application in Certain Activities details that by the sending of troops into its territory, Nicaragua is in breach of the prohibition of force and of Costa Rica's territorial sovereignty recognised under customary law and under the Charters of the UN and the Organization of American States. ${ }^{159}$ Costa Rica's memorial, quoted by the Court in its order on counter-claims, also claims that these forcible measures constitute a breach of the right of Costa Ricans to free navigation. ${ }^{160}$ In turn, Nicaragua claims that the activities of the Colombian navy near the boundary area violated the prohibition of force, Nicaraguan sovereignty over its maritime zones and Nicaragua's rights under UNCLOS and customary law. ${ }^{161}$

Similar claims have been presented to other tribunals as well. In Guyana v Suriname, Guyana claimed, and the UNCLOS Annex VII Tribunal upheld, ${ }^{162}$ that the threat of force on the CGX rig by the navy of Suriname constituted a breach of the prohibition of force under customary law and the UN Charter and a breach of the obligation enshrined in Article 279 of UNCLOS to solve disputes peacefully. ${ }^{163}$ The obligation to solve disputes peacefully was, according to both Guyana and the Court, not 'subsumed' by the prohibition of force but 'possesse[d] a specific substance of its own': ${ }^{164}$ that is, it is an obligation distinct from the prohibition of force which was breached through forcible means.

\section{3. 'Collateral breaches' of lawful self-defensive force}

The brief review in the preceding section highlights that disputes about the violation of international obligations through the use of force are very common between States, and ever-present in the docket of the ICJ. Now, if the forcible measure is one adopted in selfdefence, and which complies with the requirements of the relevant primary rules (a previous armed attack, necessity and proportionality), ${ }^{165}$ can it still constitute a breach of, say, a Treaty of Amity or of the prohibition of intervention? As highlighted by the MOX

158 Construction of a Road in Costa Rica along the San Juan River (Nicaragua v Costa Rica), ICJ, Joinder of Proceedings, Order of 17 April 2013. (unreported)

159 Application instituting proceedings (18 November 2010), Certain Activities Carried out by Nicaragua in the Border Area (Costa Rica v Nicaragua), 4.

$160 \quad$ Certain Activities carried out by Nicaragua in the Border Area (Costa Rica v Nicaragua); Construction of a Road in Costa Rica along the San Juan River (Nicaragua v Costa Rica), Counter-claims, Order of 18 April 2013, 56. (unreported)

161 Application instituting proceedings (26 November 2013), Alleged Violations of Sovereign Rights and Maritime Spaces in the Caribbean Sea (Nicaragua v Colombia), 14-15, <www.icj-cji.org>.

162 Guyana v Suriname, Award, 17 September 2007, UNCLOS Annex VII Tribunal, 147 (para 445) and dispositif at 165 (para 2).

163 Memorial, 125-128; Reply, 139ff, <www.pca-cpa.org>.

164 Guyana, Hearing Transcripts Day 4, 575-576, <www.pca-cpa.org>.

165 Nicaragua, 94 (para 176), 103 (para 194); later restated in Nuclear Weapons, 245 (para 41); Oil Platforms, 183 (para 43), 196-197 (para 74); Case Concerning Armed Activities on the Territory of the Congo (DRC v Uganda) [2005] ICJ Rep 168, 223 (para 147). 
Plant Annex VII Tribunal, multiple international legal rules can be applicable to the same conduct potentially leading to different legal appraisals. So, in a sense, a lawful use of self-defensive force may still produce 'collateral' breaches of obligations owed by that State to its aggressor. It is precisely these collateral breaches that Article 21 seeks to justify. In the next section, some examples from the practice of States will be reviewed to show that this wrongfulness-precluding effect of collateral breaches is one that seems to be generally accepted.

\section{B. $\quad$ Self-defence as a circumstance precluding wrongfulness in practice}

Practice shows that self-defence constitutes an available justification for these collateral breaches. To be sure, the practice seldom refers expressly to Article 21 (or its predecessor draft Article 34) or uses the language of secondary rules of responsibility. Nevertheless, the exonerating effect of self-defence in relation to these collateral breaches can be deduced from the findings of international tribunals and the arguments of States before them. The present review will primarily focus on judicial practice: courts' decisions as well as States pleadings. ${ }^{166}$ It is often the case that States' legal positions are more clearly articulated during legal proceedings, where the need to persuade a court of the correctness of a State's position requires a detailed and clear exposition of both facts and law. Given the rather nuanced point under examination, brief communications or interventions in international fora such as the UN, which tend to mix political and legal claims, may prove insufficient or inadequate. The review in this section will consider three clusters of obligations, which can be breached collaterally, by self-defensive force: (1) the principles of territorial sovereignty and non-intervention; (2) conventional commercial obligations; and (3) the legality of maritime exclusion zones.

\section{Territorial sovereignty and non-intervention}

Measures of self-defence may (though they need not) occur in the territory of the aggressor State. This being so, forcible measures infringe the territorial sovereignty of the aggressor State, a principle that constitutes, in the words of the ICJ in Corfu Channel, 'an essential foundation of international relations'. ${ }^{167}$ Moreover, they may also breach the principle of non-intervention, recognised under customary international law. ${ }^{168}$ From a conceptual standpoint, this means that a measure of self-defence, lawful in accordance with Article 2(4) and the customary prohibition of force, may still be a breach of the territorial sovereignty of the aggressor State and an intervention in its internal affairs. In practice, though, no one suggests that a lawful measure of self-defence constitutes a breach of these rules of international law. Practice leads, indeed, to the opposite conclusion. That lawful self-defence exercised in the territory of the aggressor does not constitute a violation of the latter's sovereignty or an intervention in its affairs can be deduced from the parties' arguments and the judgments in Nicaragua and DRCv Uganda, as well as the parties' arguments in Cameroon v Nigeria.

In the Nicaragua case, Nicaragua argued that by its conduct, including the mining and attacks on Nicaraguan ports, the US had violated both the prohibition on the use of

166 Pleadings before international courts and tribunals are generally considered as State practice, see International Law Association, 'Statement of Principles Applicable to the Formation of General Customary International Law' (Report, Committee on Formation of Customary International Law, 2000) 14. See also the observations by James Crawford and Alain Pellet at: J Crawford, A Pellet and C Redgwell, 'AngloAmerican and Continental Traditions in Advocacy before International Courts and Tribunals' (2013) 2 CJICL 1, 10-11.

167 Corfu Channel (UK v Albania) [1949] ICJ Rep 4, 35.

168 Nicaragua, 107-108 (para 205). 
force and, separately, its sovereignty through forcible measures of trespass into its territory (including its territorial waters and airspace). ${ }^{169}$ Nicaragua explained that the violation of a State's sovereignty could take place through both forcible and non-forcible means so long as there was trespass on the State's territory. In the instant case, the breach of sovereignty had been brought about through measures involving the use of force, ${ }^{170}$ including armed attacks against its territory by land, sea and air. ${ }^{171}$ Nicaragua later clarified that, 'although the claim based upon violations of sovereignty overlap[ped] with other causes of action relating to the use of force' it did not 'simply coincide with those other causes of action and consequently plays a significant independent role. ${ }^{172}$

The Court agreed with Nicaragua. The measures complained of, in addition to being acts contrary to the prohibition of force, also constituted breaches of Nicaragua's territorial sovereignty and the principle of non-intervention. ${ }^{173}$ The Court rejected that self-defence precluded the wrongfulness of these breaches because on the facts of the case the US did not have a right of self-defence, though it accepted in principle that selfdefence could have justified these violations. ${ }^{174}$ This position of principle was also explicitly endorsed by some judges in their individual opinions. Thus, Judge Jennings stated that the plea of self-defence was 'obviously a possible justification of intervention', 175 and Judge Schwebel noted that '[w] here a State is charged with an unlawful use of force, but actually has employed force in self-defence, that State is absolved of any breach of its international responsibility', such that the plea of selfdefence would constitute a complete 'defence to virtually all Nicaraguan claims'. ${ }^{176}$

In Cameroon v Nigeria, Nigeria invoked self-defence in response to the claims of State responsibility put forward by Cameroon in the context of the territorial and maritime delimitation case between the two States. ${ }^{177}$ Cameroon claimed that the Nigerian military presence in the Bakassi Peninsula and in the Lake Chad area, both areas over which Cameroon claimed sovereignty, constituted a breach of 'the most fundamental principles of international law: non-use of force ... the principle of nonintervention, respect for sovereignty. ${ }^{, 178}$ Cameroon's Memorial, submitted in 1995, also addressed possible circumstances precluding wrongfulness which might be invoked by Nigeria. In this context, Cameroon referred to self-defence and cited the then draft Article 34. The analysis in the memorial centred on Article 51 of the UN Charter, and Cameroon denied that the conditions of self-defence were met on the facts with the consequence that Nigeria could not rely on this defence for its military measures. In its

\footnotetext{
169 Memorial of Nicaragua, ICJ Pleadings, vol IV, 115 (territorial sovereignty); 117 (use of force); 120 (non-intervention).

170 Ibid, 116 (para 441): 'Many of the violations of sovereignty covered by Nicaragua's claim, and probably the majority of instances, involve the use of armed force.'

$171 \quad$ Ibid, 115 (para 438).

$172 \quad$ Ibid, 116 (para 441).

173 Nicaragua, 128 (para 251).

$174 \quad$ Ibid, 128 (para 252).

175 Ibid, Judge Jennings Diss Op, 535.

$176 \quad$ Ibid, Judge Schwebel Diss Op, 377.

177 Land and Maritime Boundary between Cameroon and Nigeria (Cameroon v Nigeria: Equatorial Guinea intervening) [2002] ICJ Rep 303.

178 Cameroon statement, CR 2002/7, 36 (para 7). (ICJ's official translation from the French). Cameroon's claims are set out in some detail in its Memorial, 596 (Section A: prohibition of the use of force), 604 (Section B: non-intervention), 608 (Section C: principle of sovereignty). For the Court's summary of Cameroon's claims see: Cameroon v Nigeria, 450-451 (para 310).
} 
response to the substance of this claim, ${ }^{179}$ Nigeria put forward a two-pronged defence. ${ }^{180}$ It began by denying that its conduct constituted a breach of the obligations claimed by Cameroon insofar as the territory where those acts had occurred belonged to Nigeria. In the alternative, Nigeria invoked two circumstances precluding wrongfulness. ${ }^{181}$ First, Nigeria claimed to be acting in self-defence. ${ }^{182}$ Second, should the Court find that Cameroon had title over the disputed areas, Nigeria claimed that it had acted pursuant to the honest belief that it held sovereignty over the territory and that, in consequence, its acts were the product of a reasonable mistake. ${ }^{183}$

Neither party explicitly stated that the plea of self-defence could act to justify alleged breaches of obligations other than the prohibition of force at issue in the case. Rather, the understanding that self-defence could justify the breach of those obligations seems to have been implicit in the parties' arguments. In its Memorial, submitted in 1995, Cameroon referred to draft Article 34 which, as noted in Section II above, had limited the justifying effect of self-defence to a single legal relation (the prohibition of force). However there is nothing in Cameroon's subsequent arguments that would limit, in principle, the effect of self-defence to the breach of the prohibition of force only: in its subsequent pleadings of 2000 (written reply) and 2002 (oral pleadings), which overlapped in time with the ILC's revision and adoption of Article 21, the argument was presented in general terms and, seemingly, in relation to all the claims. To limit the effect of the justification of self-defence to the prohibition of force only would certainly have been advantageous to Cameroon's case: even if Nigeria had been found not to have breached the prohibition of force due to self-defence, the presence of its troops in Cameroonian territory would still constitute a breach of the principles of territorial sovereignty and non-intervention thus engaging its responsibility. Yet Cameroon did not limit the plea of self-defence in this way.

Nigeria did not cite Article 21 ARS (or draft Article 34 for that matter) either. The generality of this justification and its availability in respect of the obligations that Cameroon claimed had been breached is implicit in the pleadings. A number of factors, both textual and contextual, support this conclusion. To begin with, in the oral pleadings in February 2002, Nigeria made the following clarification before the Court about a distinction crucial to its argument:

It is the distinction between the absence of a constituent element of a wrongful act, with the result that no wrongful act has taken place, and, on the other hand, a defence to State responsibility which applies so as to preclude an act, which prima facie constitutes a wrongful act, from giving rise to State responsibility. ${ }^{184}$

Self-defence, Nigeria continued, normally belonged to the latter (the circumstances precluding wrongfulness). ${ }^{185}$ It may be recalled that the ILC distinguished between selfdefence as a primary rule, in which case it is an intrinsic exception (or 'constituent element') of the prohibition of force, and self-defence as a secondary rule, in which case

\footnotetext{
179 For an analysis of its various objections on jurisdiction and admissibility see: Gray, The Use and Abuse of the International Court of Justice, 876-878.

$180 \quad$ Summarised by the Court at: Cameroon v Nigeria, 451 (para 311).

181 Emphasising the subsidiary character of this invocation, see: Nigeria statement, CR 2002/14, 33

(para 25); CR 2002/20, 28-29 (paras 18-20).

182 Counter-Memorial of Nigeria, 646 (para 24.49); Rejoinder of Nigeria, paras 15.54, 15.59-15.60; Nigeria statement, CR 2002/20, 32-33.

183 Counter-Memorial of Nigeria, 638-639 (para 24.34).

$184 \quad$ Nigeria statement, CR 2002/14, 33 (para 35).

185 Id.
} 
it acts as a circumstance precluding wrongfulness. It seems safe to assume that Nigeria's invocation of self-defence as a circumstance precluding wrongfulness mirrored the understanding of this plea in the ARS. A conclusion that is confirmed by the fact that Nigeria, which at several points in its pleadings listed the various obligations Cameroon claimed it had violated, ${ }^{186}$ did not limit its invocation of self-defence to the alleged breach of the prohibition of force only. ${ }^{187}$

An additional contextual factor may further corroborate this conclusion: Nigeria's choice of counsel. As part of Nigeria's legal team acting before the Court were Ian Brownlie and James Crawford. Brownlie had acted as counsel for Nicaragua in the case against the US which, as explained above, very clearly articulated the extent of selfdefence as a secondary rule. Crawford, in turn, had been instrumental in adapting Article 21 in the ARS to its current form in his time as Special Rapporteur for the ILC. ${ }^{188}$ Of course, there is risk in deriving conclusions about counsels' arguments on behalf of a client from arguments in other cases on behalf of other clients or from their scholarly work. Counsel are under an (ethical) duty to make the best possible legal case for a client, regardless of whether they may agree with this from a personal perspective. ${ }^{189}$ In this case this risk is minimised by the fact that there is consistency of views and that to understand self-defence as a justification for the breach of obligations other than the prohibition of force was certainly in the best interests of Nigeria, given that Cameroon claimed the breach of multiple obligations by Nigeria's use of military force.

The Court eventually upheld most of Cameroon's claims over the Bakassi Peninsula and the Lake Chad area, though it abstained from deciding on the claims concerning State responsibility due to lack of proof. ${ }^{190}$

In DRC $v$ Uganda the DRC claimed that through its forcible measures, including the continued presence of armed forces in the DRC, Uganda had breached the prohibition of force and a number of other obligations, including the principle of sovereignty and non-intervention. ${ }^{191}$ Uganda, in response, invoked self-defence to justify

\footnotetext{
186 Counter-memorial of Nigeria, 637 (para 24.32).

187 Eg Rejoinder of Nigeria, para 15.54; Nigeria statement, CR 2002/14, 18 (para 2).

188 Section II.C.

189 Under the principle of partisanship, counsel are under a duty to make the best possible legal argument for their client, on which see M Windsor, 'Government Legal Advisers through the Ethics Looking Glass' in Feldman (ed), Law in Politics, Politics in Law (Hart, Oxford 2013) 121-122. According to the ILA Hague Principles on Ethical Standards for Counsel Appearing Before International Courts and Tribunals 'counsel has a duty of loyalty to his or her client consistent with the administration of justice and the promotion of the rule of law' (art 2.1) and he or she 'shall discharge his or her professional duties in the best interest of the client, placing those interests before his or her own or those of any third party to the proceedings' (art 3.1). The Principles are printed in: (2011) 10 Law and Practice of International Courts and Tribunals 6 .

190 Cameroon v Nigeria, 452-453 (paras 319-324). This aspect of the judgment has been criticised in the literature. See, mainly, E Milano, 'Territorial Disputes, Wrongful Occupations and State Responsibility: Should the International Court of Justice Go the Extra Mile' (2004) 3 Law and Practice of International Courts and Tribunals 509; E Milano and I Papanicolopulu, 'State Responsibility in Disputed Areas on Land and at Sea' (2011) 71 Zeitschrift für ausländisches öffentliches Recht und Völkerrecht 587.

191 Memorial of the DRC, 160-193, esp 182-185 (non-intervention) and 185-186 (territorial sovereignty), 273. In the first round of oral arguments, the DRC did not discuss the principle of territorial sovereignty as an individual head of responsibility, but assimilated it to the claim of breach of the principle of non-intervention, see: DRC statement, CR 2005/2, 49-50. Yet, in its closing arguments, the DRC once again requested the Court to find that through its military action Uganda had breached the prohibition of force as well as the principles of territorial sovereignty and non-intervention: CR 2005/13, 36-37.
} 
the alleged breaches claimed by the DRC. ${ }^{192}$ Once again, the parties did not explicitly assert that the plea of self-defence had been invoked to justify the alleged breaches of the various obligations claimed by the DRC. The case was extremely fact intensive, and the parties did not dwell at length on the law concerning the circumstances precluding wrongfulness. In respect of self-defence, moreover, the majority of the parties' arguments concerned the question of the legality of its exercise against non-state actors. ${ }^{193}$ However, that self-defence could be invoked as a circumstance precluding the wrongfulness of the potential breach of obligations other than the prohibition of force is again implicit in the pleadings.

As for the DRC, in its Memorial of July 2000 it cited draft Article 34 adopted on first reading, ${ }^{194}$ and referred to this notion as the 'only' exception to the prohibition of force. ${ }^{195}$ The Memorial contains several references to Crawford's Second Report on State responsibility in which, as discussed above, he recast the draft provision on self-defence as one concerned with legal relations other than the prohibition of force. ${ }^{196}$ Furthermore, tracing the ILC's work on the matter, the DRC also explicitly excluded that self-defence could justify the breach of certain obligations deriving from human rights law and humanitarian law (the obligations of 'total restraint'). ${ }^{197}$ This express exclusion implies that the plea could justify the potential breach of other obligations, in particular those of non-intervention and territorial sovereignty that the DRC had invoked. In turn, Uganda, whose legal team included Brownlie as counsel, cited Article 21 ARS in its oral arguments, ${ }^{198}$ though it did not discuss the scope of this provision in any detail. The respondent did not put forward any specific defences for the alleged breaches of the principles of territorial sovereignty and non-intervention that the DRC had claimed, so it must have assumed that its plea of self-defence was valid in respect of these allegations too. Otherwise, even if the plea of self-defence was found to be successful, it could still be found in breach of these obligations. The Court's judgment did not refer to Article 21 ARS, though it too seems to have implicitly accepted, at least as a matter of principle, that self-defence lawfully exercised would not infringe these other obligations. Thus, after finding that self-defence had not been lawfully exercised it held that Uganda had breached the prohibition of force and, in addition, the principles of territorial sovereignty and non-intervention. ${ }^{199}$

These cases support the proposition that if forcible measures are adopted in accordance with the right of self-defence then they do not constitute breaches of the principles of territorial sovereignty and non-intervention either. Indeed, as noted by Kimberley Trapp, in addition to excepting conduct from the domain of the prohibition of force self-defence must also preclude the infringement of these other obligations. Trapp makes this point in the context of self-defence against terrorist actors, in which

\footnotetext{
192 Counter-memorial of Uganda, 180-216.

193 See, eg, Counter-memorial of Uganda, 190-216; Reply of the DRC, 206-230. In the oral pleadings see: DRC statement, CR 2005/3, 32-39; Uganda oral statement, CR 2005/7, 17-28.

194 Memorial of the DRC, 198. As noted above, on first reading the ILC had limited the scope of this defence to a single legal relation: the prohibition of the use of force

$195 \quad$ Memorial of the DRC, 232 (para 5.92).

196 See, eg, Memorial of the DRC, 198, 214, 218, 222, 233.

197 Memorial of the DRC, 232-233 (paras 5.93-5.94).

198 Uganda oral statement, CR 2005/7, 30 (para 78).

$199 D$ DRC v Uganda, 227 (para 165), 280 (para 345.1). Note that the Court only refers to the principle of non-use of force and the principle of non-intervention in the dispositif, even though the DRC had claimed also a breach of its territorial sovereignty and the Court had addressed it in its reasoning. For the DRC's prayer for relief, see: Memorial of the DRC, 273.
} 
the conceptual distinction between the prohibition of force and these two principles is more visible in that the personal target of the self-defensive force (the terrorist group) is different from the geographical location of those measures (the host State). According to Trapp, if it is accepted that self-defence may be exercised against a terrorist group located in the territory of a third State, then the exercise of that right must also excuse the breach of the host State's territorial integrity. ${ }^{200}$ Leaving aside the question of the legality of selfdefence against terrorist actors, which is beyond the scope of this paper ${ }^{201}$ the principle expressed by Trapp is certainly a general one: self-defensive force, as implied by the ICJ cases noted above, adopted in accordance with the relevant primary rule does not constitute a breach of the principles of territorial sovereignty and non-intervention.

\section{Bilateral Treaties of Amity, Commerce and Navigation}

Self-defensive measures may be incompatible with commercial obligations binding on the parties to a conflict. This was precisely one of the claims in the Nicaragua case and the principal claim in Oil Platforms, where the applicants argued that through forcible measures the respondents had breached obligations relating to the freedom of commerce, of navigation and of transit under treaty law.

In the Nicaragua case, Nicaragua claimed that the mining of, and attack on, the ports of Corinto, Puerto Sandino and El Bluff, the principal Nicaraguan ports which together handled almost all of its trade, constituted a breach of the freedom of commerce and navigation as well as the freedom of transit protected under Articles XIX(1) and XX of the 1956 US-Nicaragua Treaty of Amity respectively. ${ }^{202}$ Nicaragua recognised that these breaches could be justified under the 'exonerating causes traditionally recognised under customary law and enumerated in Chapter V' of the ARS adopted on first reading, including self-defence which had already been invoked by the US in the counter-memorial on jurisdictional objections. However, it argued that the plea was not met in fact. ${ }^{203}$ In so doing, Nicaragua was acknowledging that had the measures been a lawful exercise of self-defence, there would have been no violation of the 1956 Treaty or of the relevant customary rules. The Court accepted this position in principle, though it agreed with Nicaragua and rejected the plea on the facts: having concluded that the US's claim of self-defence was unfounded, this plea could not justify the treaty breaches either. ${ }^{204}$

The Oil Platforms case concerned the breach of various provisions of the 1955 Iran-US Treaty of Amity through the attacks carried out by the US on offshore oil complexes, owned for commercial purposes by the National Iranian Oil Corporation. ${ }^{205}$

200 K Trapp, 'Back to Basics: Necessity, Proportionality, and the Right of Self-defence against nonState Terrorist Actors' (2007) 56 ICLQ 141, 146; K Trapp, 'The Use of Force against Terrorists: A Reply to Christian J Tams' (2009) 20 EJIL 1049, 1050. This view is apparently implicit in Noam Lubell's argument in relation to the exercise of self-defence against non-State actors in foreign territory: Extraterritorial Use of Force Against Non-State Actors (OUP, Oxford 2010) 36-42.

201 On which see the exchange between Christian Tams and Kimberley Trapp in C Tams, 'The Use of Force against Terrorists' (2009) 20 EJIL 359; Trapp, The Use of Force against Terrorists: A Reply to Christian J Tams; C Tams, 'The Use of Force against Terrorists: A Rejoinder to Federico Sperotto and Kimberley N Trapp' (2009) 20 EJIL 1057.

202 Memorial, ICJ Pleadings, vol IV, 110-111. See further: Oral statement, ICJ Pleadings, vol V, 210 -

212.

203 With respect to the treaty breaches see Memorial, ICJ Pleadings, vol IV, 112 (para 427).

204 Nicaragua, 141 (para 282) (noting that the 'justification of self-defence' had already been 'rejected on the legal level').

$205 \quad$ For the claims see Oil Platforms, 166 (para 1); also 176 (para 26). 
In particular, Iran argued that the attacks on the platforms constituted a breach of article $\mathrm{X}(1)$ of the Treaty, pursuant to which '[b]etween the territories of the High Contracting Parties there shall be freedom of commerce and navigation. ${ }^{, 206}$ In response to the claim, the US relied, among others, on the plea of self-defence. As part of its defence, the US relied on the essential security exception under Article XX(1) of the Treaty of Amity and, alternatively, on self-defence as a circumstance precluding wrongfulness. Invoking the recently adopted Article 21 ARS, the US argued that its measures were a lawful exercise of self-defence and, as such, self-defence justified the alleged breach of the 1955 Treaty. Indeed "[a]ny actions of the US deemed incompatible with Article X of the Treaty would not be wrongful by the operation of this principle of customary international law. ${ }^{207}$

The US later modified this argument during the oral pleadings of the case. Its revised forensic strategy was to characterise the Treaty of Amity as a self-contained regime, thus excluding from the Court's jurisdiction any consideration of general international law. US counsel explained at length how Article XX(1)(d) constituted a lex specialis, with the consequence that, consistently with Article 55 ARS, this provision excluded the applicability to the dispute under the Treaty of the circumstances precluding wrongfulness of the (general) law of State responsibility. The US was erecting a ring fence between the dispute before the Court and general international law: the selfcontained character of the Treaty excluded consideration of the law on the use of force; the 'special' character of the defence in Article XX(1)(d) thus excluded consideration of self-defence as a circumstance precluding wrongfulness. ${ }^{208}$ This change of argument notwithstanding, not only did the US not reject in its oral pleadings ARS Article 21 as a matter of principle, but its insistence that Article XX(1)(d) of the Treaty constituted a lex specialis excluding the application of Article 21 can only be evidence that, absent the lex specialis, Article 21 would have been applicable as lex generalis.

Iran, in turn, while denying that the plea was met on the facts, agreed with the statement of principle in the American argument:

[A]ction otherwise lawfully taken in self-defence could constitute a circumstance precluding wrongfulness in relation to Article X, paragraph 1, of the Treaty. In other words, it accepts the proposition contained in Article 21 of the ILC Articles on the Responsibility of States. There is no express stipulation to that effect in the 1955 Treaty, but there does not need to be. If the US was acting in self-defence in attacking and destroying or attempting to destroy the platforms, then Article X, paragraph 1, of the Treaty is not one of the 'obligations of total restraint' of which [the Court] spoke in the Nuclear Weapons Advisory Opinion. Freedom of commerce may suffer when action is taken in self-defence; it is not an 'intransgressible' value. 209

Iran later added that, if made out, self-defence would 'exonerate the United States entirely; it would provide a complete justification for their conduct, in accordance with Article 21 of the ILC's Articles.'210

Unfortunately the Court failed to grasp the role of the plea of self-defence in the case. Instead of applying self-defence as a circumstance precluding wrongfulness, the Court chose to interpret the treaty-based exception in light of other relevant rules of

206 Iran initially pleaded breaches of arts I, IV(1) and X(1) of the 1955 Treaty of Amity, but in its preliminary objection judgment the ICJ limited the claim to breaches of art X(1), see Oil Platforms, Preliminary Objections, 821.

$207 \quad$ US Rejoinder, 141 (para 5.02).

208 See statements by Prosper Weil and Stephen Mathias on behalf of the US, CR 2003/12.

209 Iran statement, CR 2003/5, 41 (para 29). (references omitted)

$210 \quad$ Iran statement, CR 2003/7, 51 (para 3). 
international law applicable between the parties, pursuant to Article 31(3)(c) of the Vienna Convention on the Law of Treaties, ${ }^{211}$ which included the law of self-defence. ${ }^{212}$ This choice was harshly criticised by members of the Court, who viewed it as an incorporation in toto of the law on the use of force into the Treaty and, as such, an undue extension of the Court's jurisdiction under the compromissory clause of the 1955 Treaty. ${ }^{213} \mathrm{Had}$ the Court understood the role of self-defence as a circumstance precluding the wrongfulness of the treaty breaches, it would have been able to consider this plea as a rule of the general law of State responsibility without straying outside the jurisdictional boundaries imposed by the compromissory clause. ${ }^{214}$ Nevertheless, from the standpoint of State practice what is relevant for present purposes is that both parties before the Court invoked Article 21 as applicable to the treaty breaches at issue in the case and, at least as a matter of principle, understood the correct role of self-defence as a circumstance precluding the wrongfulness of collateral breaches of self-defensive force.

\section{Maritime exclusion zones}

Natalie Klein points out that in the context of military operations at sea during armed conflict:

One of the essential principles ... is that neutral shipping is not to be denied the freedom of navigation on the high seas. Rights of innocent passage, transit passage, and archipelagic sea lanes passage are all maintained for neutral shipping, as well as for belligerent vessels through neutral waters. ${ }^{215}$

The institution of war zones at sea, as areas in which States parties to conflict claim 'to be entitled to restrict the freedom of navigation and/or aviation of other States', ${ }^{216}$ evidently may affect these rights. The legality of these zones, especially when they extend to the high seas, is uncertain. ${ }^{217}$ Self-defence has been invoked to justify the potential breach of the freedom of the high seas by the institution of these zones. Although these zones may affect the rights of the aggressor and of third parties, the analysis will be limited to the relations between the two parties to the conflict.

The legality of military maritime zones was at issue in the 1982 Falklands/Malvinas conflict. ${ }^{218}$ In April 1982, following the Argentine attack on the

211 Vienna Convention on the Law of Treaties (VCLT) (adopted 23 May 1969, entered into force 27 January 1980), (1969), (1969) 1155 UNTS 331.

212 Oil Platforms, 182 (para 41). This aspect of the Court's judgment has been the subject of intense academic debate. See among others F Berman, 'Treaty Interpretation in a Judicial Context' (2004) 29 Yale Journal of Internatioanl Law 351; E Cannizzaro and B Bonafè, 'Fragmenting International Law through Compromissory Clauses? Some Remarks on the Decision of the ICJ in the Oil Platforms Case' (2005) 16 EJIL 481.

213 See, eg, Oil Platforms, Judge Higgins Sep Op, 237 (para 46); Judge Buergenthal Sep Op, 278-283; Judge Owada Sep Op, 310 (paras 13-14), 314-319.

214 That the Court has jurisdiction to apply the law of responsibility, including the award of remedies, was stated by the PCIJ in Factory at Chorzón (Merits) PCIJ Rep Series A No 17 (1928), 3, 29. It was later reaffirmed by the ICJ in LaGrand (Germany $v$ USA) [2001] ICJ Rep 466, 485 (para 48). For a similar argument see P d'Argent, 'Du commerce à l'emploi de la force: l'affaire des plates-formes pétrolières (arrêt sur le fond)' (2003) 49 Annuaire Française de droit international 266, 273-274.

$215 \quad$ N Klein, Maritime Security and the Law of the Sea (OUP, Oxford 2011) 287.

216 WH von Heinegg, 'War Zones' in R Wolfrum (ed), Max Planck Encyclopedia of Public International Law (OUP, Oxford 2009-, online edition [www.mpepil.com]), para 3.

217 Klein, Maritime Security, 296. Within certain limits, von Heinegg accepts their legality in international law: H von Heinegg, 'Current Legal Issues in Maritime Operations' (2006) 80 Int'l Legal Studies 207, 216-218.

$218 \quad$ See W Fenrick, 'The Exclusion Zone Device in the Law of Naval Warfare' (1986) 24 Canadian Yearbook of International Law 91, 116 (noting that the British zone was 'on its face an arbitrary 
islands, the UK instituted a 200 nautical mile exclusion zone around the Falklands/Malvinas directed at Argentine warships and naval auxiliaries, ${ }^{219}$ eventually extended to within 12 nautical miles of the Argentine coast, ${ }^{220}$ with the aim of facilitating military operations. ${ }^{221}$ The zone was later extended to Argentine merchant vessels and aircraft as well. ${ }^{222}$ Additionally, the UK declared a so-called 'defensive bubble' around its naval task force, which was sailing across the Atlantic towards the islands, directed to all (including third party) warships and military and civilian aircraft. ${ }^{223}$ The UK justified its measures on the basis of self-defence. ${ }^{224}$ Other than Argentina (the target of the measures), ${ }^{225}$ only the USSR officially protested the institution of the maritime zones on the basis that they breached the 1958 Geneva Convention on the High Seas, ${ }^{226}$ since they prevented the freedom of navigation on the high seas. ${ }^{227}$ Despite this protest, the UK's measures during the Falklands/Malvinas conflict were largely accepted as lawful because they were 'adopted for self-defence purposes'. ${ }^{228}$

War zones were also proclaimed during the Iran/Iraq conflict of 1980-1988, leading to what came to be known as the 'tanker war'. On September 1980, Iran declared war zones near Iranian shores and it stated that it would not allow merchant cargo shipping to Iraq. It also designated safe shipping routes. On October of that same year, Iraq declared the zone of the Persian Gulf north of $29^{\circ} 03^{\prime}$ a war zone prohibited to all shipping, expanding this zone again in 1982 and 1984 (around the Kharg Island). ${ }^{229}$ It appears that at the time neither State justified its institution of the zones on grounds of self-defence, ${ }^{230}$ though as noted below Iran would later justify their legality as an incident of its right of self-defence. In contrast to the maritime zones established by the UK in the Malvinas/Falklands conflict, the 'tanker war' affected neutral shipping. ${ }^{231}$ The zones

interference with the freedom of navigation and over-flight of aircraft and ships of non-parties to the conflict').

219 British letter, 9 April 1982, addressed to the President of the UN Security Council in (1982) 53 BYIL 539.

220 See E David, 'Les sanctions économiques prises contre l'Argentine dans l'affaire des Malouines' (1984-1985) 18 Revue Belge de droit international 150, 154.

221 See WH von Heinegg, 'The Law of Armed Conflict at Sea' in D Fleck (ed), Handbook of International Humanitarian Law (OUP, Oxford 2013) 524.

222 Letter addressed to the President of the UN Security Council, 28 April 1982, UN Doc S/15009.

223 Letter addressed to the President of the UN Security Council, 24 April 1982, UN Doc S/14997. A 'defensive bubble', as explained by Gabriella Venturini, is a three-dimensional area around a naval convoy: G Venturini, 'Air Exclusion Zones' in N Ronzitti and G Venturini (eds), The Law of Air Warfare: Contemporary Issues (Eleven, Utrecht 2006) 111 (fn 18).

$224 \quad$ See, eg, Debate on the subject of the Falkland Islands, in (1982) 53 BYIL 540 (statement by Margaret Thatcher); and the various letters to the President of the UN Security Council in (1982) 53 BYIL 539-549.

225 C Michaelsen, 'Maritime Exclusion Zones in Times of Armed Conflict at Sea: Legal Controversies Still Unresolved' (2003) 8 Journal of Conflict and Security Law 363, 373-374.

226 Geneva Convention on the High Seas (adopted 29 April 1958, entered into force 30 September 1962), (1958) 450 UNTS 11.

227 M Binyon, 'Moscow Rebukes Britain', The Times (London), 15 May 1982, p 1.

228 Fenrick, Exclusion Zone, 116.

229 ibid, 117-118.

230 R Leckow, 'The Iran-Iraq Conflict in the Gulf - The Law of War Zones' (1988) 37 ICLQ 629, 637-638.

$231 \quad$ For a review and statistics on attacks to neutral shipping see: F Wiswall, 'Neutrality, the Rights of Shipping and the Use of Force in the Persian Gulf (1990-1991) 31 Virginia Journal of International Law 619. 
established in the Persian Gulf were ultimately condemned by the UN Security Council ${ }^{232}$ and several States ${ }^{233}$ as a violation of the freedom of the high seas. The condemnation, however, was mostly a reaction to the indiscriminate nature of attacks on neutral shipping carried out by both parties. While States seemed ready to accept that, pursuant to the law of armed conflict, parties to a conflict may interfere with neutral shipping for the purpose of searching for contraband, ${ }^{234}$ indiscriminate attacks could not be justified on this basis.

At the time, neither party referred to self-defence in justification of the war zones in the Gulf. The argument of self-defence in relation to the zones was made by the UK in a statement of 1986. Consistently with the position maintained during the Malvinas/Falklands conflict, a Foreign Office Minister stated before the British parliament that:

The UK upholds the general principle of the freedom of navigation of the high seas. However, under Article 51 of the UN Charter, a State such as Iran actively engaged in armed conflict, is entitled in exercise of its inherent right of self-defence to stop and search a foreign merchant ship on the high seas if there are reasonable grounds for suspecting that the ship is taking arms to the other side of use in the conflict. This is an exceptional right $\ldots{ }^{235}$

This statement was later referred to by Iran in its pleadings in the Oil Platforms case in support of the legality of its war zones in the Persian Gulf. In the course of its pleadings, Iran explained that 'it was justified in asserting a right of visit and search, as an incident of its broader right of self-defence' and that this was recognised by 'several States', pointing to the UK's statement. ${ }^{236}$

After a thorough review of practice and literature on this question, Christian Michaelsen comes to the conclusion that 'the establishment of maritime exclusion zones seems to be legally acceptable only in circumstances of self-defence ... or when expressly authorised by the Security Council'. ${ }^{237}$ Put otherwise, the collateral breach of the freedom and peaceful purposes of the seas by maritime zones adopted in the exercise of the right self-defence is precluded, vis-à-vis the aggressor State, because of the circumstance of selfdefence. The same seems to be applicable in regard to forcible measures adopted at sea

232 UNSC: Res 540 (31 October 1983), UN Doc S/RES/540; Res 552 (1 June 1984), UN Doc S/RES/552; Res 582 (24 February 1986), UN Doc S/RES/582 and 588 (8 October 1986), UN Doc $\mathrm{S} / \mathrm{RES} / 588$.

$233 \quad 34$ States took part in the Security Council debates on Res 552 (1984); of these, at least 23 stated that the war zones in the Persian Gulf constituted a violation of the freedom of navigation on the high seas. See the summary records of the meetings at the Security Council (25 May to 1 June 1984): UN Doc S/PV.2541: Kuwait: 3 (para 17); Senegal: 8 (paras 74-75); UN Doc S/PV.2542: Ecuador: 4 (para 30); Sudan: 5 (para 38); Panama: 6 (para 57); UN Doc S/PV.2543: Bahrain: 1-2 (paras 7, 16); Morocco: 3 (paras 26-27); Somalia: 5 (para 49); Germany: 6 (paras 64, 66); UAE: 8 (Para 78); Oman: 8 (para 88); UN Doc S/PV.2545: Djibouti: 2 (paras 11, 16); USA: 3 (para 25); Turkey: 5 (para 49); Tunisia: 6 (para 62); Egypt: 7 (para 76); S/PV.2546: Netherlands: 3-4 (paras 33-34); France: 4 (para 42); Pakistan: 5 (para 51); USSR: 7 (para 69); UK: 8 (paras 74-77); India: 9 (paras 91-92); Malta: 10 (para 100); China: 10 (para 123). While the resolution focused on the conduct of Iran, during the debates the conduct of both parties was considered. See also: Fenrick, Exclusion Zone, 122; and generally: Leckow, The Iran-Iraq Conflict in the Gulf.

234 C Schaller, 'Contraband' in R Wolfrum (ed), Max Planck Encyclopedia of Public International Law (OUP, Oxford 2009-, online edition [www.mpepil.com]) paras 3-4.

235 Quoted by Gray, British Position, 423.

236 Memorial of Iran, Oil Platforms, 111-112 (para 4.59).

237 Michaelsen, Maritime Exclusion Zones, 388. See also: Klein, Maritime Security, 298; von Heinegg, The Law of Armed Conflict at Sea, 524. 
which affect enemy vessels: to the extent that they are taken for the purpose of selfdefence, they do not infringe the guarantee of the peaceful purposes of the sea. ${ }^{238}$

\section{CONCLUSION}

Contemporary international law no longer recognises a distinction between the legal status of war and the legal status of peace. When States resort to force, as the ILC put it, they do so while formally at peace. ${ }^{239}$ Thus, force occurs against the background of the complex web of legal relations which bind the States involved (and third States as well). This means that the use of force, in addition to potentially infringing the prohibition of force, can also breach multiple obligations owed by the State resorting to force to its victim. As clearly stated by the ICJ in Oil Platforms, in general, international obligations may be breached through any means: be it a legislative act, a decision of a court, or a use of force. ${ }^{240}$ The ICJ's case-law (and case-load) on this point is rather extensive: in over 20 cases filed before the Court the applicant's argument concerned the violation of its rights by uses of force of the respondent State. Of course, very often these claims are the consequence of the limits on the Court's jurisdiction, which can only often be found only in compromissory clauses in treaties thus requiring the applicant to claim a breach of that very treaty. Nevertheless, it remains the case that States claim (or respond to claims for) the breach of obligations brought about through the use of armed force.

The frequency of such claims renders the correct understanding of the scope of Article 21, codifying the secondary rule function of self-defence, rather pressing. A State acting in self-defence is 'not even potentially' in breach of the prohibition of force; selfdefence is an intrinsic element of the prohibition of force, such that the prohibition does not extend to cover self-defensive force. As a result, no breach of the prohibition can occur by the exercise of self-defensive force. But this use of force, lawful as it may be under one rule of international law, may be unlawful under another rule of international law. It does not appear that every other rule of international law is equally intrinsically limited by the circumstance of self-defence. This is, to be sure, a theoretical possibilityevery obligation could contain an 'except in the case of self-defence' condition, excluding their application in cases where self-defence is exercised-but positive law does not seem to endorse such an approach. The obligations collaterally breached are all conceptually distinct from the obligation not to use force in international relations, and the breach of any one of these rules is also conceptually distinct from the breach of any of the other rules. ${ }^{241}$ Accordingly, a condition or qualification to any one of these rules only has no effect on the breach of any of the other rules. If the right of self-defence (the relevant primary rule) constitutes an implicit condition of the prohibition on the use of force only, the legality of the forcible measure pursuant to that rule does not of necessity affect the (un)lawfulness of that same conduct under the principles of territorial sovereignty, nonintervention, freedom of the seas, the guarantee of freedom of commerce, and so on. Lawful self-defensive action, in short, can still be unlawful under other rules of international law.

238 For a review of practice see D Guilfoyle, 'The Proliferation Security Initiative: Interdicting Vessels in International Waters to Prevent the Spread of Weapons of Mass Destruction?' (2006) 29 Melbourne University Law Review 733.

$239 \quad$ ARS Commentary to art 21, para 2.

240 Oil Platforms (Islamic Republic of Iran v United States of America), Preliminary Objections [1996] ICJ Rep 803, 811-812 (para 21).

$241 \quad$ Thouvenin, Self-defence, 461. 
Yet, the review of practice undertaken in this study shows that, even if only implicitly and only in principle, States as well as the ICJ accept that lawful self-defensive force does not constitute a breach of (certain) other obligations binding the States in conflict. As the previous paragraph noted, this effect cannot be attributed to self-defence in its function as a primary rule of international law. It must then be the case that selfdefence performs also another function in international law: that of justifying collateral breaches. This is best seen as an incidental function, much in the way that preclusion of wrongfulness is an incidental function of countermeasures. The review here was limited to the effects of self-defence on the principles of territorial sovereignty and nonintervention, conventional commercial obligations, and some obligations in the law of the sea. Save for the exceptions indicated in the ILC's Commentary to Article 21, the socalled obligations of 'total restraint', there is nothing that in principle would prevent the extension of self-defence's exonerating effect to other obligations beyond these ones. For example, there is nothing to prevent the application of Article 21 to the forcible breach of treaties for the exchange of technology or other treaties for the exchange of goods or services.

To be sure, this incidental function of self-defence has not been thus far clearly articulated in most instances. With the exception of the parties in Oil Platforms, in every other case it appears that the mere invocation of the right of self-defence carries with it the assumption that the exercise of this right will also justify collateral breaches of at least some obligations. Perhaps it is for this reason that it has remained unarticulated in States' pleadings and the ICJ's decisions. It remains to be seen whether the clarification of the scope of Article 21 will result in clear and direct invocations of this provision, thus further clarifying the extent of the defence (namely, what are the limits of self-defence's function as a justification) and its role in the international order.

Finally, an important question, left open by the ILC, was that of the effect of self-defensive force on third States. ${ }^{242}$ Unlike in respect of countermeasures, ${ }^{243}$ the ILC did not affirm that self-defensive force which infringes the rights of third parties (as opposed to their interest) may not be justified by reference to the self-defensive aim of the action. The case-law analysed does not provide any indication of development in this regard, probably as a result of the Court's jurisdiction, though there seems to be growing acceptance of self-defensive interference with neutral shipping. The institution of maritime zones on the high seas and the use of forcible measures in this area, in the exercise of self-defence, may occasionally affect the rights of third parties, as the brief review of practice showed. The legality of these interferences has been widely debated, and a range of views exists on the point. ${ }^{244}$ According to the most restrictive view, only self-defence could justify the infringement of third party rights at sea. ${ }^{245}$ It is hoped, nevertheless, that this expansion of self-defence's justifying function beyond the relations between belligerents is exceptional and that, as with countermeasures, it is clarified that forcible violations of third-party rights are not, and should not, be tolerated by the international legal order.

\footnotetext{
$242 \quad$ ARS Commentary to art 21, para 5.

243 ARS Commentary to art 22, paras 4-5.

244 For a summary, see P Wendel, State Responsibility for Interferences with the Freedom of Navigation in Public International Law (Springer, Berlin 2007) 234-236.

$245 \quad$ See, generally, Guilfoyle, Proliferation Security Initiative.
} 